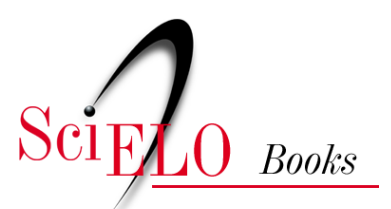

\title{
2. A Bioética e a Moralidade da Genômica
}

\author{
Fermin Roland Schramm
}

\section{SciELO Books / SciELO Livros / SciELO Libros}

SHRAMM, F. R. A Bioética e a Moralidade da Genômica. In: Três ensaios de bioética [online]. Rio de Janeiro: Editora FIOCRUZ, 2015, pp. 67-117. ISBN: 978-85-7541-586-3. https://doi.org/10.7476/9788575415863.0004.

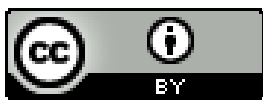

All the contents of this work, except where otherwise noted, is licensed under a Creative Commons Attribution 4.0 International license.

Todo o conteúdo deste trabalho, exceto quando houver ressalva, é publicado sob a licença Creative Commons Atribição $\underline{4.0}$. 


\section{A Bioética e a Moralidade da Genômica}

Neste ensaio abordaremos a moralidade da prática humana no campo da genômica, considerando esta disciplina como um dos principais âmbitos das atividades da biotecnociência e entendendo a biotecnociência como "conjunto de ferramentas teóricas, técnicas, industriais e institucionais que visam a entender e transformar seres e processos vivos, de acordo com necessidades e desejos de saúde", tendo como principal objetivo o "bem-estar de indivíduos e populações humanas" (Schramm, 2005: 21).

O termo moralidade indica - de acordo com uma definição de dicionário - a qualidade ou característica do que é moral, ou - dito de maneira menos genérica - a qualidade da ação humana avaliada de acordo com um juízo de valor que em princípio permite dizer se está correta ou não. Mas o termo é entendido e utilizado de várias outras maneiras pertinentes. Pode, por exemplo, ter relação com aquilo que uma pessoa, um grupo ou uma sociedade deseja, professa ou faz; ou seja, referir-se às "práticas e opiniões efetivas de uma sociedade [ou] que deveriam existir", considerando deveres "cuja aplicação é independente de qualquer ato legislativo" (distinguindo a moralidade da legalidade), ou referir-se à oposição entre moralidade (Moralität) e eticidade (Sittlichkeit). Tal oposição foi introduzida por Hegel para indicar "o que diz respeito ao indivíduo autônomo" (a moralidade) e apresenta uma "incompatibilidade potencial 
com valores sociais comuns já estabelecidos e com os costumes e instituições que dão corpo e sustentam esses valores" (a eticidade) (Mautner, 2010b: 509-510, destaques do original).

O termo pode ser referido também a uma característica ou a um "valor (positivo ou negativo) do ponto de vista do bem e do mal", aplicável "tanto às pessoas como aos juízos e aos atos" (Lalande, 1972b: 656). Nesse sentido, moralidade pode se referir tanto ao agente como a seus atos, o que permite falar em moralidade do agente e moralidade do ato, ou seja, considerando como pertinente uma característica ou qualidade de quem age (como quando se diz de alguém que é boa ou má pessoa), movido, por exemplo, por um dever; ou - de acordo com as consequências da prática do agente moral - devido a uma característica ou qualidade daquilo que é produzido por quem age, e que pode ser visto como independente das motivações do agente.

No âmbito da filosofia moral, um dos primeiros sentidos específicos do termo moralidade é aquele proposto por Kant na Fundamentação da Metafísica dos Costumes (1785) e na Crítica da Razão Prática (1788), em que o filósofo distinguia moralidade e legalidade. Articulando-as sem separálas, Kant considerava serem ambas expressão de nossa relação com a lei, entendendo legalidade como mera conformidade da ação às normas morais vigentes e moralidade como a qualidade da ação quando o agente moral é movido pela "intenção pura" do "respeito pelo dever", pois "a legalidade da ação está englobada em sua moralidade, mas as exigências da moralidade ultrapassam aquelas da legalidade" (Pariente-Butterlin, 2000: 55); em ambos os casos sem ter em conta as consequências da ação nem as contingências socioculturais em que esta se efetiva.

Um segundo sentido específico se refere às consequências de um ato, seja este voluntário ou involuntário, previsto ou não. Esse é o sentido adotado pelo utilitarismo a partir de J. Bentham, que formulou, em sua Introdução aos Princípios da Moral e da Legislação ([1789] 2007), o princípio de utilidade, segundo o qual um ato é moral se promover maior quantidade de felicidade, ou seja, de prazer e ausência de dor.

Tendo em conta os conteúdos da deontologia kantiana e aqueles do consequencialismo dos utilitaristas, aqui o termo moralidade será entendido no 
sentido inclusivo de característica do ato humano, analisada e julgada de acordo com parâmetros valorativos que permitam dizer se este é correto ou incorreto, justo ou injusto, em determinada situação e tendo em conta não somente as boas intenções, mas também suas consequências. Por sua vez, a ética será entendida como o estudo da moralidade dos atos humanos, considerados corretos ou incorretos de acordo com determinadas características, como aquela - destacada pela deontologia - do agente moral capaz de cumprir seus deveres (como aqueles contidos em sua deontologia profissional) ou aquela destacada pela abordagem consequencialista - de produzir bem-estar ou evitar sofrimento não necessário.

Neste ensaio, a pergunta que norteia nossa investigação pode ser formulada da seguinte maneira: o que do trabalho dos profissionais da genômica poderia ter de moralmente desejável ou questionável, levando-se em conta os possíveis efeitos positivos e/ou negativos sobre a qualidade de vida dos humanos e dos seres vivos em geral, uma vez que as ferramentas da genômica são aplicáveis a qualquer ser e sistema vivo?

Trata-se de pergunta aparentemente retórica, pois parece sugerir que estaria em questão a liberdade humana de conhecer e pesquisar. Mas isso seria contrário a toda a história da produção cultural humana amplamente entendida a partir da Idade Moderna, quando surge a ciência experimental, em princípio inseparável da criatividade e da autonomia dos pesquisadores, pois "a liberdade permite fazer coisas que os objetivos específicos programados ou planejados não permitem". Embora, atualmente, o novo modo de "produção, apropriação e regulação dos saberes ligado ao neoliberalismo [tenha] modificado em profundidade a paisagem da pesquisa", criando "mercados do conhecimento" e implicando que "uma concepção estreita da pesquisa científica e do trabalho dos pesquisadores tenda a ser erigida como modelo dominante" (Catellin, 2014: 214).

Ademais, a pergunta pode parecer inapropriada se considerarmos a reduzida extensão do conceito de moralidade, aplicado àquilo que o senso comum considera como moralmente correto, ao invés de referir-se ao universo constituído pelos prós e contras, como exige o significado técnico do termo, que se refere a um objeto que deve ser abordado por "uma atividade racional e uma pesquisa crítica" (Mori, 1997: 12). 
Entretanto, apesar das possíveis dificuldades que acabamos de apontar, a pergunta é pertinente e justificada se a referirmos ao duplo sentido - cognitivo e moral - do verbo poder. Duplo sentido que perpassa a história da cultura desde a época mitopoiética grega, começando pelo pensamento religioso e a filosofia antiga até chegar aos nossos dias, quando ela constitui uma interrogação fundamental tanto da epistemologia e da metodologia como da própria ética e da política.

Portanto, falar em moralidade da genômica faz sentido se considerarmos a genômica como uma prática que implica "o estudo da estrutura e funcionamento do material genético total (genoma) de um organismo" (Salzano, 2004: xiii) e se aplica concretamente na prática biotecnocientífica, a qual envolve não só conhecimentos (conceitos, teorias) e técnicas, mas também dispositivos $^{5}$ que implicam relações de poder entre pesquisadores, sujeitos pesquisados, financiadores, indústria e mercado. E isso porque tais relações inevitavelmente resultam em conflitos de interesses, que constituem um dos tópicos mais candentes da problemática ética em pesquisa dos últimos anos, devido especialmente à sua relação com a cultura dos direitos humanos e, em particular, com os direitos dos sujeitos (ou pessoas), objetos de pesquisa, diante do dispositivo biotecnocientífico.

A expressão conflito de interesses, registrada nos dicionários da língua inglesa desde 1971, vem sendo utilizada hoje na ética dos negócios, na ética das profissões e, de forma crescente, também na ética pública, podendo-se dizer que pertence atualmente à linguagem de qualquer código deontológico e de qualquer cálculo de tipo utilitarista. De fato, seu significado pode ser referido ao "conflito entre um dever público e um interesse privado", o que pode "influenciar o cumprimento dos deveres ligados ao [primeiro]" e introduz no debate o problema de uma "previsível falta de confiabilidade do juízo de quem se encontra em tal situação de conflito" (Cremaschi, 2006: 2.182). Entretanto, conflito de interesses deve ser distinguido de "conflito entre deveres", que implica - como o nome indica - uma incompatibilidade entre deveres; isto é, em princípio uma impossibilidade (ou incapacidade) de cumprir um dos

\footnotetext{
${ }^{5}$ De acordo com Giorgio Agamben (2006: 22), um dispositivo é um instrumento de poder que tem “a capacidade de capturar, orientar, determinar, interceptar, modelar, controlar e assegurar os gestos, as condutas, as opiniões e os discursos dos seres vivos".
} 
deveres concorrentes (e que pode se caracterizar em determinadas situações como um dilema moral), mas sem que isso afete necessária e substancialmente o juízo, ao passo que o conflito de interesses implica sempre "influenciar a normal capacidade de juízo" (Cremaschi, 2006: 2.182).

No campo da saúde - em que pretendemos situar este ensaio -, o termo conflito de interesses adquire, de acordo com o bioeticista Sergio Zorrilla (2007: 65),

pelo menos desde a Declaração de Helsinque, um estatuto particular, por ser entendido como processo e fonte de riscos para os direitos humanos dos sujeitos da experimentação [e] como perturbação e desestabilização constante do bom equilíbrio entre dois imperativos: por um lado, a prioridade absoluta de preservar a saúde e o bem-estar do ser humano para além dos interesses da ciência e da sociedade, e, por outro lado, a necessidade permanente de recorrer à experimentação humana, à inovação terapêutica e tecnológica, com a finalidade de também preservar a saúde do ser humano.

Para o autor, essa dupla obrigação moral ante um mesmo objetivo se daria no âmbito de uma série de mudanças sociológicas ocorridas no campo da pesquisa e das relações que esta mantém com a economia e a biotecnociência "no contexto de uma produção massiva" de pesquisadores e médicos e de uma "divisão crescente entre dirigentes e dirigidos". Em tal contexto, caberia reconhecer, nas "duras exigências do mercado de trabalho", "uma fragilidade da consciência do pesquisador" para resolver adequadamente os conflitos de interesses, pois "para muitos, queiramos ou não, o primeiro interesse [consiste] em ter acesso ao trabalho e à própria reprodução da vida" (Zorrilla, 2007: 70-71).

Assim, poder-se-ia dizer que "durante as últimas décadas, o ethos dominante no mundo da ciência tem mudado de forma insidiosa", porque o que era "um empreendimento coletivo [e] compartido é atualmente limitado, com frequência, pelas exigências da competição comercial", com muitos pesquisadores que "só compartem suas descobertas com o resto da comunidade sob a proteção da lei das patentes ou do segredo comercial" e outros "se agarrando aos velhos ideais da ciência" (Sulston \& Ferry, 2003: 2-3).

Apresentadas essas considerações introdutórias à problemática da moralidade da genômica, podemos entrar no mérito de sua avaliação, feita pela ética e pela bioética. 


\section{A Avaliação da Moralidade da Genômica entre Tecnofilia e Tecnofobia}

Historicamente, a avaliação da moralidade das práticas biotecnocientíficas, constituídas pelo uso das biotecnologias e referentes ao saber da genômica, tem recebido uma série de respostas que podem ser situadas entre dois polos opostos:

1) o polo representado pelos "tecnofílicos" ou "entusiastas panegíricos da técnica", que, amparados no princípio de beneficência ou de realização, "prescrevem aceitar e aplaudir as conquistas da técnica" e só admitem "as primícias genéticas que podem favorecer a saúde humana";

2) aquele dos "tecnofóbicos", que partem da premissa de que toda técnica é perigosa e de que "seu perigo aumenta proporcionalmente ao seu grau de complexidade e sofisticação" e, amparados pelo princípio da não maleficência ou da conservação (e, em alguns casos, da precaução), exigem "pôr barreiras onde essas primícias acarretam verdadeiros riscos para a saúde" ou "relações de domínio [que perturbam o] equilíbrio etológico" (Maliandi \& Thüer, 2008: 233-241).

Para Maliandi e Thüer, diante de tais atitudes polarizadas, que impedem o diálogo, seria mais razoável adotar uma atitude de convergência, a qual "pode admitir a técnica, e, portanto, a biotecnologia, como imprescindível e, inclusive, admirável, desde que não se percam de vista, ao mesmo tempo, os inúmeros perigos que ela implica", pois uma "aprovação com precaução será sempre uma atitude mais razoável que [uma] aprovação sem precaução ou [uma] precaução sem aprovação" (Maliandi \& Thüer, 2008: 242).

\section{Os dois tipos de resposta e seus argumentos}

Os dois tipos de resposta - as dos tecnofílicos e as dos tecnofóbicos - à pergunta inicial sobre a moralidade da prática da genômica se baseiam nos argumentos que apresentaremos a seguir:

1) Sim, estamos autorizados a saber tudo aquilo que somos capazes de saber devido à curiosidade legítima que nos caracteriza e às ferramentas operacionais e cognitivas que possuímos - estruturadas e sistematizadas pelas ciências e pelas técnicas ao longo de suas histórias respectivas, e organizadas pelos seus dispositivos de produção, divulgação e controle. 
De acordo com esse argumento, saber e saber-fazer seriam algo em princípio positivo e legítimo, visto que servem para entender os fenômenos e a nós mesmos, tentando transformá-los - e nos transformar - quando isso for considerado necessário (ou talvez simplesmente desejável), e visando, em última instância, a resolver problemas para melhorar a qualidade de vida das pessoas e das populações humanas.

2) Não estamos autorizados a saber tudo o que em princípio temos competência cognitiva para saber, e haveria, portanto, um conhecimento proibido, visto que "nossas descobertas dos segredos da natureza, cada vez mais audazes, podem ter chegado a um ponto em que o conhecimento nos traz mais problemas do que soluções, [pois] aprendemos a fazer certas coisas muito antes de saber o que estamos fazendo e de maneiras que ninguém pode explicar de forma adequada" (Shattuck, 1998: 15-16). Por isso, só deveríamos saber e saber-fazer o que não é contrário a tal interdição ou não prejudique a nós e aos outros seres que compõem, juntos, o nosso mundo, por cuja gestão somos coletiva e pessoalmente responsáveis, inclusive no sentido de proteger os melhores interesses das gerações futuras e a sustentabilidade do próprio planeta - que deve ser preservado (ou protegido) contra eventuais danos evitáveis ocasionados por esses tipos de saber em suas aplicações.

Numa primeira avaliação crítica, podemos dizer que a primeira resposta é aparentemente menos problemática do ponto de vista moral, pois parece intuitivamente aceitável argumentar que o saber, ao aumentar a competência do Homo sapiens (que é também Homo faber) para compreender o mundo e a si mesmo, seja algo desejável e em princípio legítimo, inclusive para aplicá-lo concretamente, tendo em vista a preservação ou o aprimoramento da qualidade de vida humana (e, eventualmente de outros seres vivos e dos ambientes). Mas essa resposta pode se tornar problemática se considerarmos, por exemplo, que a pesquisa científica "[confia] numa certeza não explicitada de que a liberdade total no intercâmbio dos produtos simbólicos da mente não afeta de maneira necessariamente adversa o domínio da vida diária e é bem capaz de aperfeiçoá-lo" (Shattuck, 1998: 19-20), visto que não teríamos em devida conta os efeitos que podem ser positivos e/ou negativos - da cultura científica sobre nossas vidas. Ou se pensarmos na modificada condição antropológica e sociológica 
atual, em que é praticamente impossível separar a competência do Homo sapiens daquela do Homo faber, isto é, se relacionarmos o saber teórico (ou logoteórico) e o saber-fazer técnico (ou tecnopoiético), que se tornaram de fato inseparáveis desde que a ciência se transformou em tecnociência e as ciências biológicas em biotecnociência e biotecnologias. Ou seja, se pensarmos ao mesmo tempo no processo de conhecer o real e naquele de transformá-lo, assim como nas inter-relações desses dois processos, e compreendermos o que é o homem e tentarmos transformá-lo em suas características - adquiridas durante o longo processo biológico chamado evolução - justificando tal intervenção com vantagens comparativas (reais ou supostas) ou com valores morais que parecem convergir para algum tipo de beneficência ou um bem, mas que, em realidade, são dificilmente convergentes e nem sempre aceitos por todos os atores sociais racionais envolvidos (ou que possam vir a se envolver no futuro).

Entretanto, na primeira resposta raramente se faz a distinção (clássica) entre o aspecto logoteórico da elaboração do conhecimento e o aspecto tecnopoiético de sua produção, sendo que o aspecto tecnopoiético quase sempre está ainda subsumido no logoteórico, de acordo com uma concepção tradicional de ciência, separada de suas aplicações tecnocientíficas e biotecnocientíficas. Embora, no novo contexto globalizado em que se constrói o saber-fazer tecnocientífico e biotecnocientífico, os "temas de pesquisa [sejam] definidos de maneira demasiado estreita por interesses industriais ou por grupos de pressão, com objetivos de curto prazo tendo em vista resultados rapidamente aproveitáveis" (Catellin, 2014: 207). Assim, saber como é o mundo e ser capaz de transformá-lo parecem tornar-se, ambos, moralmente corretos, pelo menos se considerarmos que tais operações visam, em última instância, a melhorar ou, pelo menos, a manter a qualidade de vida dos humanos, presentes e futuros, em um mundo transformado, inclusive devido a causas de origem antrópica. Isso estaria ocorrendo, sobretudo, graças aos avanços da biomedicina - e da saúde pública - nos âmbitos da prevenção, da previsão e do tratamento de moléstias e doenças antes não tratáveis. Em suma, nesse contexto, conhecer e saber-fazer seriam moralmente preferíveis à ignorância e à "incompetência".

Mas a uma inteligência (ou sensibilidade) atenta aos avanços da biotecnociência e às várias percepções e simbolizações a seu respeito, e sem 
preconceitos - ou posições apriorísticas - sobre tais avanços, frases como "não se deve querer saber tudo" ou "nem tudo aquilo que é tecnicamente possível é moralmente legítimo" - dois dos principais chavões que circulam no imaginário social - podem parecer pelo menos estranhas. E isso, basicamente, por dois motivos. Primeiro porque, em realidade, não sabemos tudo nem fazemos tudo o que sabemos - haja vista a contínua troca de paradigmas científicos ao longo da história das ciências e os avanços técnicos, científicos e biotecnocientíficos que, ao longo do tempo, tornaram nossas práticas mais efetivas, muitas vezes abandonando técnicas e procedimentos vigentes. Segundo, porque parece cada vez mais sensato pensar que a própria sobrevivência da espécie humana dependa não somente da mudança de comportamentos e de padrões de consumo - que devem ser, em última instância, sustentáveis -, mas também dos meios propiciados pela ciência e pela técnica. Ou, mais precisamente, de uma sábia aliança entre as capacidades do Homo faber e aquelas do Homo sapiens, em princípio capazes de controlar os eventuais deslizes do Homo sapiens demens (Morin, 1973).

Não sabemos tudo porque, de acordo com o estudo das condições do conhecimento - abordadas pela epistemologia e pela metodologia -, só se pode saber algo a partir de algum ponto de vista. $\mathrm{Ou}$ - se levarmos em conta os aspectos metodológicos do processo concreto de conhecer - de um conjunto de pontos de vista diferentes e pertinentes, que podem relacionar-se entre si de diferentes maneiras. Por exemplo, de maneira meramente pluridisciplinar na análise de um fenômeno, em que os pontos de vista não têm uma relação direta entre si; ou de maneira um pouco mais ambiciosa, chamada interdisciplinar, em que diferentes pontos de vista se inter-relacionam; ou, então, numa autêntica relação transdisciplinar, entendendo a transdisciplinaridade como "etapa (...) em que não bastaria atingir as interações ou reciprocidades entre pesquisas especializadas [como na interdisciplinaridade], mas que situaria tais laços no interior de um sistema total sem fronteiras estáveis entre disciplinas" (Piaget, 1972: 144). Mas, de qualquer maneira, nunca de todos os pontos de vista possíveis, pois isso exigiria ou um ser-que-sabe-tudo (metaforizado pela imagem de um deus onisciente) ou um dispositivo capaz de saber tudo (uma espécie de máquina pensante com poderes cognitivos infinitos como aquelas representadas pela ficção científica). Em outros termos, devido a tais limites da 
razão humana - já destacada pela epistemologia kantiana (Kant, 1989) - e da linguagem humana - destacada por Wittgenstein (2005) -, não podemos saber tudo porque não existe um ponto de vista - ou não conseguimos imaginar tal existência de maneira cogente - que contenha todos os pontos de vista possíveis, capazes de dar conta de tudo (a não ser, talvez, matematicamente, como conjunto transfinito contendo todos os infinitos, algo de fato dificilmente representável e realizável).

No entanto, o lema que reza que nem tudo aquilo que sabemos fazer deve ser feito é intuitivamente válido do ponto de vista moral, pois, por exemplo, sabemos matar, embora isso não implique necessariamente a passagem ao ato (pelo menos não sem uma boa razão). Mas quando o lema está associado ao assim chamado imperativo tecnológico - pressuposto segundo o qual o dispositivo representado pela biotecnociência seria algo cego, irresistível e que se imporia ao Homo sapiens/demens independentemente da sua aceitabilidade do ponto de vista moral, assim como de seus riscos presentes e futuros -, podem surgir questionamentos sobre sua pertinência e legitimidade. De fato, como acabamos de lembrar, só se sabe algo de acordo com algum ponto de vista e com alguma intenção cognoscente - o que resulta sempre em um conhecimento limitado e focado -, e só se pode saber-fazer algo a partir do interesse e/ou do desejo de realizar concretamente algo tendo algum saber pressuposto, e realizando esse saber concretamente.

Em outros termos, a primeira resposta deixa em aberto as implicações da questão da ignorância (e do direito ao não saber), que, por falta de uma abordagem crítica, só pode ser indicada por imagens negativas como aquelas do mítico vaso de Pandora, cheio de perigos; ou aquela do destino do Prometeu da mitologia antiga, punido pelos deuses por ter dado o fogo e seus poderes de transformação ao Homo faber; ou, ainda, pela imagem do Fausto de Goethe, que vende a alma ao diabo em troca do saber. São imagens de fato reutilizadas atualmente sobretudo pela ficção científica.

A segunda resposta é mais próxima àquela parte do imaginário contemporâneo preocupada não só com os benefícios - reais ou potenciais - do saber científico e do saber-fazer tecnocientífico, mas também com os riscos implicados pela utilização de seus produtos e procedimentos, e com os eventuais 
efeitos adversos (e perversos) de nossas ações no futuro, ações praticamente impensáveis no presente, visto que se baseiam nos saberes e nas modalidades de saber-fazer - sempre limitados - que temos atualmente e em seus dispositivos de controle sempre imperfeitos.

Mas essa problemática nos obriga a enfrentar duas outras questões, interligadas:

1) a questão objetiva das relações entre ciência e técnica, e de suas transformações em tecnociência e biotecnociência, que implicam cada vez mais efeitos previstos e efeitos imprevistos sobre o real e sobre a qualidade da vida humana presente e futura, os quais dependem de nossas ações responsáveis, ou não, sobre o mundo e sobre nós mesmos;

2) a questão subjetiva da relação entre a competência técnica do Homo faber e a competência racional do Homo sapiens, indicada, de forma problemática, pela expressão imperativo tecnológico, identificada a uma espécie de destino e que de fato subsume a competência do Homo sapiens àquela do Homo faber, suscitando, portanto, questões eticamente relevantes, como aquela da liberdade e da responsabilidade - presente e futura - dos cientistas e dos técnicos que trabalham no âmbito da biotecnociência, capaz de transformar o mundo e o próprio homem.

Entretanto, a primeira resposta - a dos tecnofílicos - tem uma variante: aquela que considera a biotecnociência como uma resposta correta à condição humana de neotenia.

\section{O argumento da neotenia para justificar o uso da biotecnociência}

O conceito de neotenia foi desenvolvido pela biologia do desenvolvimento para indicar um desenvolvimento incompleto em algumas espécies animais, indicando "[a] persistência no desenvolvimento de uma espécie de caracteres próprios de estádios larvares ou pré-adultos" (Dicionário Rex) ${ }^{6}$ ou "pedomorfose produzida pelo retardamento do desenvolvimento somático, de maneira que a maturidade sexual é atingida em um organismo que retém

\footnotetext{
${ }^{6}$ Disponível em: <http://senhordaspalavras.com.br/significado/neotenia>. Acesso em: 6 maio 2013.
} 
características juvenis", entendendo-se pedomorfose como "presença de caracteres primitivamente juvenis, larvais ou embrionárias em um organismo adulto" (Houaiss \& Vilar, 2001: 2.164).

A ideia central desse conceito - o desenvolvimento incompleto - servirá aqui para indicar a condição humana de incompletude e as tentativas do Homo sapiens de responder a tal limitação (ou pelo menos de contorná-la) graças aos avanços da biotecnociência, e que a bioética analisa a partir de sua caixa de ferramentas, a qual permite a articulação entre três questões que, em nosso entender, embora distintas, não devem ser separadas:

1) a questão da condição humana caracterizada, ao nascer, pela imaturidade biológica e pelo desamparo psicológico, que implica um ser vivo pouco especializado e em princípio adaptável a qualquer nicho ecológico;

2) a questão da aventura humana, caracterizada pela construção e pelo uso da tecnociência e da biotecnociência, e que em princípio permite auxiliar a primeira natureza do Homo sapiens - que é de tipo biológico - com uma segunda natureza - que é técnico-cultural -, podendo-se dizer que tais artefatos realizam uma espécie de síntese entre as competências tanto do Homo faber como do Homo sapiens; e

3) a questão dos meios supostamente capazes de orientar, controlar e/ou limitar o agir humano, como as ferramentas da bioética, as quais são de tipo descritivo-compreensivo e de tipo prático-normativo, e se ocupam das práticas humanas que podem ter consequências irreversíveis sobre o mundo, entendido como entidade constituída por sistemas vivos integrados em seus ambientes ou contextos.

Em realidade, o humano é neotênico e desamparado, imaturo e desprotegido com relação ao ambiente no qual terá de sobreviver. Essa característica é comum a praticamente todos os mamíferos e mostra a importância dos cuidados parentais com a prole nesse estágio evolutivo da matéria viva, proteção sem a qual o pequeno Homo sapiens em princípio não sobreviveria. Por isso, a técnica e a cultura em geral constituem duas vantagens comparativas que nossa espécie construiu ao longo de sua história para sobreviver, tomar conta do mundo e transformá-lo conforme seus desejos e projetos, inscritos em sua práxis. 
Em particular, graças à revolução cultural representada pela emergência e afirmação do paradigma biotecnocientífico em meados do século $\mathrm{XX}, \mathrm{o}$ humano tornou-se em princípio competente para reprogramar, a princípio ad libitum, o mundo natural, inclusive para reprogramar-se a si mesmo conforme seus desejos, projetos e necessidades. É isso que poderíamos chamar de biotecnologização do mundo, a qual constitui um dos campos problemáticos abordado pela bioética, que, nesse caso, pode ser vista como instância normativa das práticas no âmbito da biotecnociência, tendo em vista a proteção diante da vulnerabilidade ou da efetiva vulneração dos sistemas vivos e de seus ambientes, inclusive a vulnerabilidade/vulneração da espécie humana, ameaçada pelos próprios seres humanos e seus projetos e produtos. Por isso, poder-se-ia dizer que há um nexo lógico entre a vulnerabilidade/vulneração da condição humana, a criação dos meios sociais, técnicos e culturais do humano para contornar as limitações decorrentes dessa condição existencial e as formas de controle contra os abusos dos meios humanos aplicados ao mundo da vida.

De fato, a qualidade de vida dos humanos existentes e das gerações futuras assim como o bem-estar dos animais sencientes e a qualidade do meio ambiente - parecem depender cada vez mais daquilo a que podemos chamar de revolução biotecnocientífica, cujos avanços conceituais e cujas principais aplicações práticas se dão nos âmbitos da genômica e, em particular, nas realizações das biotecnologias e da engenharia genética (e mais recentemente da nanotecnologia). Em outros termos, os produtos da biotecnociência - ou biotecnologias - deixaram de ser meros produtos da ficção científica para se tornar parte do mundo real, objeto de esperanças e/ou de temores. E isso porque "sabemos que [com] a biotecnologia tudo mudará, mas não sabemos como serão tais mudanças", pois "devido ao que se pode perder, trata-se do maior risco que o gênero humano já enfrentou", sobretudo se levarmos em conta que "o máximo perigo reside em que o poder de decisão sobre o que devemos fazer está nas mãos de quem é movido por interesses que não são ou não são eminentemente - aqueles de quem aponta esses riscos ou visa ao seu controle" (Maliandi \& Thüer, 2008: 234-235).

Por isso, a biotecnociência pode ser encarada como um "novo e desconcertante desequilíbrio etológico" e um "imenso risco social", visto que 
se trata sempre também de uma forma de poder (e de biopoder), diante do qual seriam necessárias duas atitudes: "a vontade de minimizar os conflitos (evitando-os, resolvendo-os ou regulando-os) e o reconhecimento de que todo o social está estruturado de maneira conflituosa" (Maliandi \& Thüer, 2008: 238-239).

Resumindo, se é verdade, por um lado, que "a rapidez do progresso tecnológico, em particular do progresso biotecnológico, tem semeado desordem em nossas categorias morais", por outro "os novos procedimentos sempre provocam advertências alarmantes". Por essa razão, "os progressos na colheita e disseminação das informações, tornadas possíveis graças à biotecnologia, não se afastam de maneira radical dos temores conhecidos acerca da relação entre conhecimento e poder", visto que "se pode abusar de qualquer técnica e não há conhecimentos, nem informação, que não sejam suscetíveis de manipulação para fins moralmente ruins". Nesse caso, nossa tarefa deverá ser a de "ficarmos atentos e impedir tais abusos" (Harris, 1992: 235).

A biotecnociência pode ser chamada literalmente de revolução - no seu sentido de "reviravolta, alteração [das] condições políticas ou sociais, mas não necessariamente súbita, abrupta ou violenta" (Mautner, 2010g: 651) porque seu saber-fazer permite não só compreender e transformar os sistemas vivos e seus contextos naturais (como já sabia, em parte, fazer a tecnociência tradicional dos engenheiros), mas também - graças à reprogramação de sua informação e constituintes - adaptá-los às necessidades, desejos e projetos humanos, inclusive quando isso implica reprogramar o próprio agente da reprogramação: o homem.

Concretamente, a medicina genômica permite ampliar as possibilidades diagnósticas, preventivas e preditivas, revolucionando, dessa maneira, a concepção e o campo da saúde humana, e talvez até a própria compreensão que o ser humano tem de si. Mas é também uma constante da história humana que uma revolução cultural - científica ou não - polarize a opinião e a percepção dos especialistas e do público em geral entre aqueles que veem na revolução em questão uma razão para grandes esperanças e aqueles que, ao contrário, a percebem com profunda apreensão. Assim aconteceu historicamente com a revolução copernicana, com a darwiniana, com a freudiana, e agora parece estar 
acontecendo com a revolução biotecnocientífica, pois o fenômeno constituído pela vigência do paradigma biotecnocientífico é motivo de esperanças e de temores.

De fato, para uns, especialmente para aqueles que têm a qualidade de suas vidas comprometida por doenças e moléstias de origem genética e, por isso, acreditam que os progressos da biotecnociência poderão evitar em grande parte essa condição de desvantagem comparativa perante seus semelhantes sadios -, a revolução biotecnocientífica é motivo de esperança. Ademais, para essa categoria de pessoas - que indicamos acima com o termo tecnofílicos é também lógico que a competência biotecnocientífica seja vista como uma dádiva; portanto, como uma ferramenta moralmente legítima a ser utilizada, e, por isso, é possível que a "mãe natureza" seja vista menos como uma boa mãe e mais como uma madrasta. Para outros, a revolução biotecnocientífica é também motivo de apreensão, quando não de verdadeiro temor, sobretudo para aqueles que, em princípio, não têm nenhum motivo sério para queixas quanto à sua saúde e à qualidade de sua vida (e à "mãe natureza"). Para essa categoria de pessoas, que indicamos com o antônimo tecnofóbicos, a revolução biotecnocientífica é tida prevalentemente como um grande risco, aparentemente não indispensável, e como uma interferência arriscada e perigosa nos complexos e delicados processos naturais, construídos "sabiamente" ao longo dos milênios pela "mãe natureza". Pode, portanto, revelar-se coisa de aprendizes de feiticeiros, incapazes de controlar as consequências de seus atos, como bem indicado pela expressão playing God - muitas vezes traduzida impropriamente por "brincar de Deus" quando se deveria traduzir por "fazer o papel de Deus", isto é, criar -, que exprime de fato a transformação do Homo faber e sapiens em Homo faber, sapiens e creator (Anders, 1980).

No entanto, em ambos os casos surge também uma pergunta de forte conteúdo especificamente moral: será que o humano não deveria pagar o preço de sua liberdade para essa "ousadia", isto é, arcar com as consequências de suas escolhas como ser que tem os meios para construir o mundo não necessariamente conforme as leis naturais, mas sim de acordo com as normas culturais e os projetos humanos de melhoria do bem-estar? Afinal, viver é correr riscos, e o risco zero é uma situação ideal que nunca existiu, como já tentavam mostrar a mitologia e o pensamento mitopoiético antigos ao falarem 
da condição edênica (se considerarmos o conto da expulsão do Éden). Portanto, o risco faria parte da própria estrutura da liberdade humana, razão pela qual não haveria nenhum argumento substantivo capaz de legitimamente exigir tal ausência de risco no caso da revolução biotecnocientífica, sobretudo tendose em conta seus enormes benefícios potenciais. É preciso, portanto, se dedicar ao difícil labor de ponderar riscos e benefícios em condições de incerteza (que abordaremos no terceiro ensaio desta coletânea, sobre as relações entre bioética e biossegurança).

\section{A questão da moralidade da engenharia genética}

Um dos produtos da biotecnociência que mais suscitam questionamentos de tipo moral é a engenharia genética, uma forma de saber-fazer que consiste em manipular a composição genética dos organismos vivos, graças à utilização das biotecnologias (eventualmente combinadas com as nanotecnologias), e em eliminar (ou pelo menos controlar) características não desejadas ou introduzir novas características desejadas. Quando o uso da engenharia genética resulta na combinação do material genético de organismos pertencentes a espécies diferentes, fala-se em organismos transgênicos (ou organismos geneticamente modificados, OGM), que são objeto de verdadeiras guerras políticas entre quem preconiza seu uso como resposta adequada às nossas necessidades - por exemplo, alimentares, para substituir tecnologias consideradas obsoletas ou para responder a necessidades de saúde - e quem, ao contrário, quer bani-los por considerá-los mera fonte de riscos e danos a serem absolutamente evitados.

Mas a competência em manipular organismos vivos a fim de melhorar suas qualidades em prol do bem-estar humano é tão antiga quanto a Revolução Agrícola, acontecida há mais de dez mil anos no Oriente Médio, onde o homem aprendeu intuitivamente e a partir da experiência a selecionar e cruzar animais e plantas para obter descendentes melhorados (por exemplo: mais produtivos e adaptados). Entretanto, seu planejamento racional só se tornaria possível graças aos avanços da biologia molecular a partir dos anos 1970, da genômica a partir dos anos 1990 e da nanotecnologia a partir do século XXI.

Do ponto de vista epistemológico, o surgimento da engenharia genética representa uma verdadeira transição paradigmática na maneira de pensar o ser vivo e de agir sobre ele. Com efeito, a vigência do paradigma 
biotecnocientífico pode ser vista como um desdobramento do próprio paradigma da vida (representado pela biologia) graças à integração do saberfazer tecnocientífico dos engenheiros aplicado aos sistemas vivos e a seus ambientes (que analisamos em detalhes no primeiro ensaio desta coletânea). Mas essa transição paradigmática, que atinge tanto o saber-fazer, representado pela biotecnociência, quanto o saber-agir (que tem implicações morais e políticas, ou - se preferirmos - bioéticas e biopolíticas), foi insuficientemente pensado tanto pela própria filosofia como pelas ciências humanas e sociais em geral, sendo quase sempre mostrado ou imaginado pela ficção científica e pelos meios da realidade virtual na forma de ameaças ou belas quimeras, sem entrar realmente no meio-campo constituído pela ponderação entre riscos e benefícios da maneira mais razoável possível.

Quando alguém tentou abordar essa transformação com seriedade, pensando, por exemplo, o sentido da revolução antropogenética nos termos paradoxais de uma crescente dependência da sobrevivência da espécie humana da revolução biotecnocientífica, por um lado, e dos custos dessa dependência, por outro - ou seja, da nova condição humana que consiste na intensificação da dependência da técnica, graças à qual o Homo sapiens passa da condição de criatura do mundo para aquela de criador de mundos (Sloterdijk, 2000) houve, sobretudo, reações de tipo emocional e pouco racionais. Nesse tipo de reação esquece-se de considerar, por exemplo, as qualidades emergentes e particularmente atuantes da verdadeira revolução na biosfera que permitiu o aparecimento do mamífero humano, chamado Homo faber e Homo sapiens, que tem se tornado um Homo creator.

De fato, faltou considerar as condições atuais do saber-fazer biotecnocientífico, as reais possibilidades e as implicações antropológicas e ecológicas das práticas desse novo tipo de ser, resultante da aliança entre a competência técnica do Homo faber e a competência racional do Homo sapiens, chamado também de Homo creator por ser capaz de produzir não só objetos, mas também entes vivos projetados, criados e consumidos. Faltou, em particular, aprofundar a análise da ambivalência perceptiva da competência biotecnocientífica do Homo creator, de suas práticas e seus produtos, que trazem para as sociedades contemporâneas o desafio de uma previsão talvez impossível e de uma avaliação de riscos e benefícios para os humanos (presentes e futuros). 
Por fim, faltou incluir, em tal análise, e sobretudo em seu cômputo final, os outros seres vivos e os ambientes, partindo da premissa - em parte resultante de constatações empíricas, em parte de pressupostos metafísicos - de que todos esses entes e seres estão vinculados uns aos outros e, portanto, são interdependentes, podendo então interagir em uma suposta grande, complexa e dinâmica cadeia do ser (ou "ser em devir").

Em outros termos, esse trabalho de análise paciente de um sistema hipercomplexo deve ainda ser feito à luz da competência e das performances implicadas na recente revolução biotecnocientífica, preocupando-se com a correta articulação da frágil condição biológica do humano ao nascer (neotenia) com a potência criadora e/ou destruidora do humano adulto, detentor do saber da linguagem e da técnica e, talvez, de alguma forma de sabedoria sobre o bem e o mal.

Embora esse trabalho de meditação sobre as implicações, tanto existenciais como morais e políticas, da biotecnociência fique em aberto, vale a pena lembrar alguns antecedentes na própria história da filosofia ocidental. Trata-se de pensadores que tentaram aprofundar as implicações existenciais e, em geral, filosóficas do mundo transformado pela tecnociência, como veremos a seguir.

\section{Breve histórico da conceituação de técnica pela filosofia}

A interrogação sobre a técnica na cultura ocidental é antiga. Platão já considerava a técnica como "o paradigma da relação que o homem estabelece com todos os objetos" e "procede do encontro de dois conhecimentos do objeto: o do artesão e o do usuário do objeto", mas vinculado ao conhecimento verdadeiro, julgado como "a única condição possível do domínio de qualquer atividade", sendo o primeiro conhecimento subordinado ao segundo (Brisson, \& Pradeau, 2010: 70-71). O filósofo sugeria também, no Protágoras, que a forma particular de ação humana chamada técnica seria um presente do titã Prometeu, que, comovido pela vulnerabilidade humana, teria dado ao homem a técnica de usar o fogo, roubando-o dos deuses e capacitando, dessa maneira, o humano tecnicamente. Ademais, no Eutidemo, Platão chamara a política considerada a atividade cidadã mais importante - de "técnica régia" (basiliké téchne) e usara a metáfora da técnica da tecelagem para indicar a essência da atividade de governar (Platone, 1974). 
Em realidade, o mito platônico remete, indiretamente, à própria neotenia humana, pois os humanos - pouco aparelhados no plano orgânico e desprovidos de meios suficientes de defesa ao nascer - seriam os únicos animais a não poder sobreviver sem instrumentos artificiais para aperfeiçoar sua natureza e não desaparecer. Esse mito tem, portanto, uma relação com a experiência, pois, ao nascer, o humano é um ser desamparado, imaturo e desprotegido em relação ao ambiente no qual terá que sobreviver, razão pela qual deverá ser inicialmente protegido para se manter vivo, até se tornar suficientemente capacitado para viver e tomar as decisões das quais em princípio dependerá sua qualidade de vida.

A técnica e a cultura em geral constituem as vantagens comparativas que nossa espécie construiu ao longo de sua história para compensar sua neotenia e sobreviver, tomar conta do mundo e transformá-lo conforme desejos e projetos, sensatos ou insensatos que sejam. Graças à revolução cultural representada pela emergência e afirmação do paradigma biotecnocientífico em meados do século $\mathrm{XX}$, o humano tornou-se capaz de reprogramar - como já vimos - o mundo vital (Lebenswelt), inclusive a si mesmo, o que podemos chamar de biotecnologização da vida. Assim, pode-se estabelecer um nexo entre a vulnerabilidade da condição humana, a criação dos meios sociais, técnicos e culturais do humano para contornar, de algum modo, a condição de vulnerabilidade e as formas de controle contra os abusos dos meios humanos aplicados ao mundo vital.

Mas é somente no século XX que uma reflexão consistente sobre a técnica se consolida, reconhecendo que as descobertas científicas e as inovações tecnológicas em qualquer campo da atividade humana têm não somente facilitado a vida dos humanos, mas também a transformado completamente. Por isso, tais descobertas e inovações são vistas como uma espécie de Jano de duas faces que ajuda o homem, mas a um preço considerado por alguns muito alto, pois poderia levar ao desaparecimento da liberdade e da própria vida orgânica como um todo (Schramm, 2000).

Diante desses riscos e/ou perigos, implicados pela competência biotecnocientífica, alguns filósofos têm feito uma reflexão não só sobre a atuação e o sentido das várias técnicas, mas também sobre a assim chamada "essência" da 
técnica e sobre como deveríamos lidar com ela, devido a seus possíveis efeitos negativos sobre o mundo vital e sobre a própria identidade do ser humano.

A seguir, apresentaremos a posição de quatro pensadores que se debruçaram sobre essas questões ao longo do século XX: Ernst Jünger (1895-2000), Martin Heidegger (1889-1976), Hans Jonas (1903-1993) e Arne Naess (1912-2009).

\section{A 'mobilização total' pela técnica de Ernst Jünger}

Jünger parte das noções nietzschianas de vontade de potência (Wille zur Macht) e ultra-homem (Übermensch) para indicar, com a primeira noção, a situação de movimento total e impessoal da técnica, e com a segunda o efeito de selecionar uma nova "raça" de humanos, capaz de fazer com que esse movimento total da técnica, em vez de aniquilar o homem, seja por ele vivenciado e dominado. Para indicar tal movimento, o autor utiliza o conceito de mobilização total (totale Mobilmachung), que seria a capacidade de pôr em movimento a totalidade de matéria e energia potencialmente disponíveis no universo. Como escreveu o autor, "a mobilização total se cumpre por ela mesma (...) ela é [a] expressão de uma lei misteriosa e inexorável [na qual] cada existência individual se torna, sem que o mínimo equívoco possa subsistir por muito tempo, uma existência de trabalhador" (Jünger, 1990: 113).

Para Jünger, essa mobilização total tornaria todos os humanos trabalhadores e só seria possível graças à técnica e ao aperfeiçoamento e desenvolvimento de tecnologias. Ademais, ela não seria um fenômeno casual e contingente, mas algo inevitável e necessário, inscrito na própria história da humanidade. Por fim, técnica e mobilização total implicariam a expropriação da liberdade, porque a técnica não seria algo possuído pelo homem como um instrumento em seu poder, mas por ser o próprio homem uma parte do processo técnico; em suma, porque seria a técnica a dominar o homem, e não o inverso.

A análise de Jünger destaca, com lucidez, o caráter potencialmente alienante do processo tecnológico, pois a técnica se imporia, de maneira inexorável, como uma necessidade, e o homem que nela se instala não poderia controlar plenamente nem suas regras e linguagens, nem seus efeitos. No entanto, o autor sugere que esse empoderamento técnico, indicado pelo termo tecnologia planetária (que será retomado por Heidegger, como veremos a seguir), teria 
necessariamente um preço alto, pois o ser humano deveria pagar seu bemestar e sua segurança com perda de sua liberdade e autonomia.

\section{A essência da técnica como Ge-stell de Martin Heidegger}

Impressionado com aquela que ele considerara uma das melhores compreensões da metafísica nietzschiana, Heidegger pensa que o conceito de mobilização total de Jünger permite enxergar o domínio da vontade de potência que, em sua forma técnica, teria adquirido - no século XX - uma dimensão planetária. Mas Heidegger pretende ultrapassar a análise de Jünger, introduzindo, em sua desconstrução metafísica, o conceito de verdade entendida como acontecimento (Ereignis) do ser, isto é, considerando o ser como aquilo que, por essência, se subtrairia ao controle do homem, mas, ao mesmo tempo, só se daria na relação com o homem, naquela que o autor chama clareira (Lichtung) em que pode colocar-se o "ser aí" (Dasein) do próprio homem. Esse acontecimento mudaria com o tempo e as épocas históricas - que correspondem às várias modalidades em que o ser se dá e ao mesmo tempo se subtrai -, e em época contemporânea essa manifestação do ser se daria no contexto da técnica.

Mas qual seria a essência da técnica?, pergunta Heidegger. E responde: o Ge-stell (neologismo que significa tanto composição como arrazoamento e armação, ou dispositivo), conceito ao qual o filósofo alemão chega depois de aplicar o método filológico à análise do verbo stellen (pôr, dispor), declinando as várias modalidades do dar-se da técnica de acordo com os vários significados de seus verbos compostos: vor-stellen (representar), be-stellen (ordenar, encomendar) e her-stellen (produzir), que seriam manifestações particulares (indicadas pelas preposições vor, be e her) de uma única atitude: aquela indicada pela semântica do verbo stellen, cujo significado revelaria a essência da técnica. Como explica o autor,

O ordenar (Be-stellen) põe. Provoca. Mas se o pensarmos em profundidade em sua essência, e não segundo seus possíveis efeitos, ordenar (...) passa rapidamente de um ordenável ao sucessivo [porque] tem antecipadamente trazido e posto tudo aquilo que está presente dentro da completa ordenabilidade, independentemente do fato de que, no caso individual, tal ente presente já se apresente de forma particular ou não. (Heidegger, 1994: 29) 
Entretanto, a vários aspectos dessa única atitude técnica corresponderiam significados distintos. Por exemplo, a técnica "provoca" na medida em que obriga algo a se manifestar, fazendo-o sair do estado de escondido, e para mostrar isso o autor cita o caso da Terra, a qual estaria instada a se apresentar em sua totalidade como recurso ordenável e explorável, não tanto pelo possível lucro almejado, mas, essencialmente, como algo ordenável. Portanto, esse ordenar em que tudo estaria ordenado em função de outro ordenar - se estabilizaria como algo efetivamente ordenado, logo como recurso subsistente ou fundo de reserva (Bestand). O próprio homem seria uma peça desse mecanismo do ordenar, embora tenha também um papel na atuação desse ordenar.

Diferentemente de Jünger, que destacara a ambiguidade da técnica como alienante e eventualmente controlável pelo ultra-homem nietzschiano, mas ao preço de sua liberdade, Heidegger faz um prognóstico mais pessimista sobre a possibilidade de a técnica ser controlada e dirigida pelo homem numa perspectiva não técnica. Por isso, não adiantaria nos opormos à técnica, visto que não podemos nos subtrair a seus dispositivos (a seu Ge-stell), pois, como evento extremo da metafísica ocidental, iniciada por Platão - a quem Heidegger "atribui a desvalorização dos objetos naturais e dos produtos humanos" (Steiner, 2001: 233) -, e que reduziria todos os seres a meros entes, a técnica deveria ser deixada ao seu destino - o qual seria também o nosso sem se pretender mudá-la.

Entretanto, essa meditação de Heidegger sobre a essência da técnica e as modalidades de seu revelar-se é bastante obscura e indica o contexto niilista (já presente em Jünger) das discussões sobre tecnociência e biotecnociência que se seguiriam, pois muitas das análises posteriores sobre o niilismo tecnocientífico se inspiram na meditação heideggeriana. De fato, Heidegger afirma que a técnica em sua forma atual - conhecida a partir dos anos 70 do século XX como tecnociência - seria a metafísica realizada de nosso tempo, pois reduziria a totalidade da Lebenswelt (mundo da vida) a um mero fundo de reserva, graças à potência do agir racional, técnico e operacional.

Mas o autor passa, sem mais, dessa descrição sobre a essência da técnica que pode eventualmente ser aceita como uma ontologia da técnica, embora seja certamente também uma preocupação metafísica - para outro plano, o 
existencial. Nesse plano se daria a submissão inevitável do homem contemporâneo à racionalidade tecnocientífica, o que consistiria, em substância, em subsumir o universo dos fins ao dos meios, pois isso seria um destino (Geschick), o que implicaria o aniquilamento da liberdade de escolha (como já indicado por Jünger).

Para caracterizar essa condição existencial do homem contemporâneo, Heidegger indaga aquela que chama de essência da técnica, indicada - como já vimos - pelo neologismo Ge-stell. Mas essa essência da técnica implicaria uma condição niilista, ou seja, uma "nadificação do Ser", em razão de sua objetivação técnico-metafísica, situação que poderia ser indicada pela expressão contraintuitiva "tudo aquilo que é tecnicamente possível fazer será necessariamente feito" (independentemente de esse fazer poder ser considerado um bem ou um mal).

Porém, quem não aceita essa aniquilação da dimensão ética, implicada pelo imperativo tecnológico niilista, muitas vezes permanece prisioneiro dessa mesma lógica, pois pensando combater tal niilismo - e os supostos abusos da tecnociência implicados - simplesmente inverte o sentido da expressão, considerando, sem mais, que "nem tudo aquilo que é possível fazer deve ser feito", ficando, portanto, muito aquém da discussão crítica instigada pelas posições do autor.

Em uma avaliação crítica da meditação heideggeriana, uma das objeções que podem ser feitas - sobretudo a partir da vigência do paradigma biotecnocientífico atual - é que sua análise sobre a essência da técnica resulta não de uma subsunção dos fins aos meios, mas, mais diretamente, em uma confusão entre meios e fins. Isso talvez explique o fato de Heidegger nunca ter proposto explicitamente uma ética em seu sistema filosófico, a não ser algumas considerações éticas gerais contidas na Carta sobre o Humanismo, de 1949, que inauguraria de fato "um campo de pensamento trans-humanista ou pós-humanista" (Sloterdijk, 2000: 22). Uma dessas considerações éticas gerais pode ser inferida, por exemplo, de sua preocupação de "superar a metafísica", a qual pode ser vista como "simultaneamente e em última instância um chamamento para 'salvar a terra', precisamente porque a tecnologia exploradora e o culto da ciência, supostamente objetiva, representam a culminação natural da metafísica ocidental a partir de Platão" (Steiner, 2001: 237). 
Aplicando a reflexão heideggeriana ao caso específico da biotecnociência, pode-se dizer que a confusão se dá entre seus meios - como aqueles da engenharia genética - e os fins correlacionados, representados pela procura do bem-estar e da melhoria da qualidade de vida dos sujeitos necessitados e que poderiam recorrer a ela. Com efeito, se o arrazoamento (Ge-stell) parece ser, por um lado, necessário para explicar como se aprende a utilizar determinada técnica - visto que sempre teremos que nos submeter a determinadas condições para seu uso correto (e isso vale para aprender a dirigir, utilizar um computador, falar uma língua, aprender uma especialidade como a engenharia genética nas faculdades de biologia, tomar um remédio, lidar com as pessoas etc.) -, por outro já nesse nível de aprendizagem uma dinâmica muito sutil entre tentativas e erros implica, muitas vezes, atos de autêntica criatividade, que consistem em descobrir novas maneiras de utilizar uma técnica ou uma linguagem específica já existente. Em suma, a relação entre meios e fins pode muito bem ser vista como da ordem de uma dialética, mais que daquela do imperativo tecnológico e do consequente niilismo tecnocientífico subjacente. De acordo com "a densa idiossincrasia do estilo tardio de Heidegger" (aquele do ensaio sobre a técnica, publicado em 1953), "superar a metafísica" e "salvar a terra" são chamamentos inseparáveis, pois "na mesma época do mecanismo niilista, a esperança volta a ser acessível", como parece mostrar a referência ao poeta Hölderlin, com a qual Heidegger conclui seu ensaio: “Onde está o perigo, cresce também o que pode salvar" (Steiner, 2001: 237).

Entretanto, por dever deimparcialidade, deve-se dizer também queas análises de Heidegger tiveram o mérito de apontar o fato de a ciência contemporânea ser inseparável da técnica; isto é, de toda ciência ser inexoravelmente uma tecnociência; um saber que é ao mesmo tempo um fazer, ou uma competência simultaneamente racional, técnica e operacional. Essa caracterização da ciência contemporânea como um saber que é de fato sempre um saber-fazer, isto é, um dispositivo que tem uma dimensão intrinsecamente pragmática, permite que se analisem seus fatos (como aqueles da engenharia genética) do ponto de vista moral. Por exemplo: aplicando-se as ferramentas analíticas e normativas da bioética à atuação do paradigma biotecnocientífico, visto que a bioética estuda inter alia justamente a nova forma da práxis humana na vigência do paradigma biotecnocientífico, cujos fatos se tornam objetos legítimos de análise por parte 
da ética porque se referem diretamente aos efeitos - considerados benéficos ou maléficos - das ações sobre outros humanos e os seres vivos em geral.

De fato - e de acordo com o paradigma bioético (Hottois, 1990) -, se pensarmos nos efeitos irreversíveis, reais ou potenciais, da vigência da biotecnociência, veremos que não se pode mais falar impunemente na neutralidade da ciência, visto que justamente "a ciência tem se tornado um meio da técnica" (Ellul, 1954: 8), podendo, portanto, agir sobre a própria estrutura da vida e, talvez indiretamente, sobre o tipo de escolha humana, ou de sociedade e de instituição desejáveis. Aliás, é por isso que existe, além de uma filosofia da ciência (que se ocupa da consistência e da fidedignidade das hipóteses e teorias científicas), uma sociologia da ciência (que se ocupa das implicações sociais desse saber-fazer) e, sobretudo, uma bioética da ciência (que se ocupa das implicações morais do saber-fazer tecnocientífico e biotecnocientífico) e uma biopolítica da ciência (ou aplicação dos dispositivos políticos à humanidade como espécie).

Portanto, para evitar tanto a ideologia do endeusamento beato da ciência dos tecnofílicos quanto a ideologia tecnofóbica de sua demonização - que indicamos pela imagem mitológica do Jano de duas faces -, devemos saber distinguir não só os meios e os fins, mas também os fatos e os valores, pois sem essa distinção renunciaríamos à prática da crítica em prol da mera aceitação ou recusa ideológica (ou emocional) da ciência transformada em tecnociência e biotecnociência. Tal preocupação crítica implica, ainda, termos provavelmente que renunciar às visões holísticas da ciência - que não sabem identificar e definir esse todo que a ciência é - em prol de uma visão complexa, a qual permite saber "distinguir sem separar e juntar sem confundir" seus vários aspectos entrelaçados (Morin, 1990).

Quem irá introduzir, de forma explícita, a meditação sobre as implicações morais e éticas da vigência da biotecnociência será um ex-aluno de Heidegger: Hans Jonas.

\section{Hans Jonas e o 'princípio responsabilidade’ na Idade da Técnica}

O pensamento de Jonas se inscreve naquele movimento de "transformação da filosofia", resultante da "confrontação entre a pergunta hermenêutica 
pelo sentido do ser e a crítica do sentido da linguagem, efetuada pela filosofia analítica" (Apel, 2000: 9), conhecido também como filosofia prática. Na cultura alemã, tal movimento surge durante os anos 60 do século XX e está preocupado com a dimensão concreta do agir humano e com o tipo de racionalidade que $o$ sustenta, partindo dos pressupostos de que o homem não só pensa e observa, mas, sobretudo, age, e ao agir utiliza técnicas de vários tipos que afetam - ou podem afetar - outros humanos, outros seres vivos, os ambientes naturais, podendo, inclusive, "mudar o universo" (Sulston, 2007: 17). Portanto, seu comportamento tem consequências importantes sobre o bem-estar e a qualidade de vida dos outros (amplamente entendidos: outros humanos e seres vivos em geral) e de si mesmo, tornando-o, assim, responsável por seus atos e suas consequências.

Em uma publicação autobiográfica, o autor revela que sua preocupação com a problemática da técnica se deve, sobretudo, ao fato de esta - segundo a lição heideggeriana - ter transformado o saber científico, antes entendido como mera teoria, em um saber-fazer técnico, que é "eminentemente prático [e] determina cada vez mais a vida de todos nós", razão pela qual deveríamos considerar atentamente esse aspecto preocupante, "para que ele não se transforme, para nós, em um destino que, sem nos darmos conta, temos procurado". Isso o teria "obrigado a passar da razão teórica à razão prática, isto é, à ética", em que não é mais "o prazer do conhecimento, mas o medo do futuro ou a preocupação para com o homem" que motivam o pensamento entendido como "um ato de responsabilidade" (Jonas, 1987: 26).

$\mathrm{Na}$ avaliação de Jonas, na idade de vigência da técnica moderna - e tendo em conta seus efeitos a longa distância e a longo prazo sobre o mundo vital - a própria natureza do agir humano teria mudado substantivamente, e, portanto, também a responsabilidade pelos seus atos. Para o autor, isso exigiria uma transformação na própria concepção do papel da ética, a qual teria a tarefa autocrítica de questionar seu antropocentrismo, o pressuposto da natureza imutável da natureza humana e o quadro temporal limitado das consequências da ação, pois o campo de ação da técnica abrangeria hoje o inteiro espaço da biosfera e já teria produzido danos irreparáveis no ambiente. Por isso, argumenta Jonas, surgiria a questão pertinente e legítima do valor moral da natureza, que a ética contemporânea não poderia esquecer e deixar de abordar. 
Para Jonas, dever-se-ia considerar que a técnica aplicada ao mundo vital colocaria em questão o pressuposto fundamental da moral - a imutabilidade e intangibilidade da natureza humana - porque hoje já sabemos e podemos intervir tecnicamente sobre o patrimônio genético humano e transformar, de maneira significativa e irreversível, as estruturas biológicas, os corpos e, talvez, as mentes. Em outros termos: o homem já poderia assumir sua própria evolução, e isso demandaria saber se o humano atingirá o patamar do alémhumano (ou além-do-homem) nietzschiano (já indicado por Jünger), "capaz de dizer Sim a todas as coisas" e, portanto, de "autossuperação" (Tanner, 2004: 74-76). Mas, nesse caso, deveríamos nos perguntar que sentido teria uma ética humana que analisasse a prática de quem decidiu as transformações a serem feitas no genoma humano, tendo em conta o argumento prudencial referente à imprevisibilidade incontrolável da ação tecnológica, a qual faria - segundo a visão de Jonas - aumentar a probabilidade de insucesso mais do que aquela do sucesso.

Em sua obra mais conhecida, O Princípio Responsabilidade, Jonas ([1979] 2006) aprofunda sua análise e argumenta que, pela primeira vez na história da humanidade, devemos considerar seriamente a hipótese do aniquilamento de toda forma de vida no planeta Terra. E que, consequentemente, devemos também nos perguntar sobre a moralidade da transformação da natureza humana, devido ao uso, cada vez mais intensivo, da técnica, capaz de modificar a própria identidade orgânica e, talvez, psíquica do Homo sapiens, que - como já lembramos - deve ser visto também - e simultaneamente - como Homo faber e Homo creator.

Em realidade - para Jonas - e ao contrário do que comumente se pensa, o Homo faber já teria ultrapassado o Homo sapiens:

Hoje, na forma da moderna técnica, a techne transformou-se em um infinito impulso da espécie para adiante [e essa] conquista de um domínio total sobre as coisas e sobre o próprio homem surgiria como a realização de seu destino. Assim, o triunfo do homo faber sobre o seu objeto externo significa, ao mesmo tempo, o seu triunfo na constituição interna do homo sapiens, do qual ele outrora costumava ser uma parte servil. (Jonas, [1979] 2006: 43) 
Mas essa superação da competência racional pela competência técnica implicaria a ideia de que "a tecnologia assume um significado ético por causa do lugar central que ela agora ocupa subjetivamente nos fins da vida humana", pois

sua criação cumulativa, isto é, o meio ambiente artificial em expansão, reforça, por um contínuo efeito retroativo, os poderes especiais por ela produzidos, [exigindo seu] emprego inventivo incessante [para] manterse e desenvolver-se, recompensando-o com um sucesso [que] contribui para o aumento de suas ambições. (...) $\mathrm{Na}$ imagem que [o homem] conserva de si mesmo [ele] é cada vez mais o produtor daquilo que ele produziu e o feitor daquilo que ele pode fazer; mais ainda, é o preparador daquilo que ele, em seguida, estará em condições de fazer. Mas quem é "ele"? Nem vocês nem eu: importam aqui o ator coletivo e o ato coletivo, não o ator individual e o ato individual; e o horizonte relevante da responsabilidade é fornecido muito mais pelo futuro indeterminado do que pelo espaço contemporâneo da ação. Isso exige imperativos de outro tipo [e] a moralidade deve invadir a esfera do produzir, da qual ela se mantinha afastada anteriormente, e deve fazê-lo na forma de política pública [pois] a natureza modificada do agir humano altera [também] a natureza fundamental da política. (Jonas, [1979] 2006: 43-44)

Para dar conta dessa nova situação existencial, a ética tradicional seria insuficiente. Para Jonas, o segundo imperativo categórico kantiano formulado na Metafísica dos Costumes - "Age de modo tal que uses a humanidade tanto em tua pessoa como na pessoa de todo outro sempre ao mesmo tempo como fim, jamais simplesmente como meio" - se mostraria insuficiente por ser fundamentalmente o princípio de uma ética da reciprocidade entre aqueles que compõem a sociedade humana: ao dever de um corresponde o direito de outro, e vice-versa. Mas a ética da reciprocidade não seria mais válida - argumenta Jonas - quando entram em jogo as gerações futuras, que não podem reivindicar diretamente seus direitos, o mesmo acontecendo com animais e outros seres vivos, embora tenhamos deveres específicos para com eles.

Por essas razões, à ética da reciprocidade Jonas opõe uma ética da responsabilidade, segundo a qual nós somos responsáveis pelas nossas escolhas, inclusive com relação àqueles que não podem (ainda) fazer valer seus direitos.

Quase duas décadas depois, Jonas publica uma aplicação do princípio de responsabilidade à prática da biomedicina - Ética, Medicina e Técnica - em que pondera: 
Limito-me a indicar o princípio da ordem de preferência: quanto mais pobres em conhecimento, motivação e liberdade de decisão forem os indivíduos (...), tanto mais parcimoniosamente e mesmo relutantemente deveria a provisão deles ser usada, e tanto mais imperativa tem pois de tornar-se a ordem de razões em contrário.

Note-se que isto é o oposto de um padrão de utilidade social, o inverso do ordenamento por "disponibilidade e sacrificabilidade": os elementos mais valiosos e escassos, menos sacrificáveis, do organismo social hão-de-ser os primeiros candidatos ao risco e ao sacrifício. É o padrão da noblesse oblige; e com toda a sua antiutilidade e aparente "prodigalidade", pressentimos nela uma rectidão e talvez mesmo uma superior "utilidade", pois a alma da comunidade é pelo espírito que vive. É também o oposto daquilo por que clamam os interesses quotidianos da investigação, e para que a comunidade científica lhe faça as honras é mister que lute contra a forte tentação de se dirigir, por inércia, às fontes de suprimento mais à mão - aqueles que são mais sugestionáveis, mais ignorantes, mais dependentes, que mais "amarras" têm em vários sentidos. Não creio que uma resistência intensificada deva aqui estropiar a investigação, o que não pode ser permitido; mas pode efectivamente abrandá-la pelos menores números que em consequência disso irão alimentar a experimentação. Tal é o preço - uma vez mais brando coeficiente de progresso - que poderá ter de ser pago pela preservação do mais precioso capital de uma superior vida comunitária. (Jonas, 1994: 150-151)

\section{Comparando as três posições}

Na comparação das posições dos três autores citados, pode-se constatar que todos expressam um sentimento de desamparo, e de quase impotência, em relação ao poder considerado impessoal e incontrolável da técnica. Mas a posição de Jonas é a única das três que expressa claramente (diferentemente de Heidegger, que a deixa somente aparecer metaforicamente como uma esperança ante o perigo) uma possível solução com sua proposta de uma ética da responsabilidade. Esta - em nossa leitura - estabelece as condições de possibilidade para uma vinculação do paradigma biotecnocientífico com o paradigma bioético, a qual implicaria uma reformulação do pensamento filosófico tradicional para se pensar em uma nova convivência possível - e não catastrófica - entre homem, natureza e técnica, dirigida por humanos que devem necessariamente ser responsáveis. 
Em realidade, como vimos, para Jonas - contrariamente a Heidegger a técnica não é, em si, nem boa nem má, pois quando foi bem utilizada permitiu uma efetiva melhora das condições de vida dos humanos (como mostra, por exemplo, boa parte da história da medicina). Mas isso não permite idolatrá-la como um instrumento capaz de resolver todos os problemas, porque o desenvolvimento tecnológico já tem tido também consequências devastadoras - por exemplo, para o ambiente natural - e claramente imorais, inclusive na própria medicina, como no caso dos médicos que atuaram durante a vigência de biopolíticas de extermínio. De qualquer maneira, a técnica teria transformado radicalmente a condição humana, e isso implicaria também uma reformulação da ética, tanto no sentido de um aprofundamento das questões inéditas trazidas pela vigência do paradigma biotecnocientífico quanto no de uma ampliação inédita do campo da moralidade, pela inclusão de novos sujeitos, como o mundo humano futuro, o mundo animal e o ambiente natural, lídimos objetos (ou destinatários) da aplicação do paradigma bioético atualmente.

\section{A 'ecologia profunda' de Arne Naess}

Sobre essa ampliação do campo da consideração moral - e tendo-se em conta a pertinência e a legitimidade de se aplicar a ética às questões ambientais -, devemos lembrar brevemente outro autor, o filósofo norueguês Arne Naess, formulador da ecologia profunda (deep ecology), abordada em um artigo de 1973 e desenvolvida no livro Ecologia, Comunidade e Estilo de Vida (Naess, 1989). Nessa obra, o autor opõe ao tradicional antropocentrismo - que já havia sido criticado por suas limitações, inclusive por Jonas, mas que Naess considera como "o sintoma de um mal mais profundo: o individualismo" e segundo o qual "a realidade é constituída, em última instância, de seres independentes uns dos outros" (Goffi, 2001:352). Em substituição, Naess propõe uma ecosofia capaz de superar o antropocentrismo vigente mediante um biocentrismo segundo o qual a vida como tal teria valor intrínseco, ou seja: todas as formas de vida, e não somente as humanas, teriam o igual direito de existir e de se realizar plenamente. Tal biocentrismo levaria, para Naess, a um igualitarismo biosférico, pois todos os seres vivos estariam de fato conectados entre si como os nós de uma rede, e a qualidade de vida de uma forma viva dependeria da relação instaurada com as outras formas de vida, o homem sendo nada mais 
que um desses nós, apesar de suas especificidades. Isso implicaria novos estilos de vida, mais frugais, isto é, caracterizados pela simplicidade dos meios e pela riqueza dos fins, fundados em uma nova forma de sabedoria relativa ao oikos ou casa-Terra.

É a essa posição que o autor chama de ecologia profunda (deep ecology), contraposta à tradicional ecologia superficial (shallow ecology), a qual só se preocuparia com a poluição ambiental e a finitude dos recursos naturais, conservando substancialmente os padrões de vida e de consumo dos habitantes dos países desenvolvidos. A ecologia profunda, por sua vez, seria capaz de originar uma igualdade de direitos entre todas as formas de vida da biosfera, o que poderia implicar termos que pensar seriamente em modificar tais padrões, inclusive abandonando o ponto de vista antropocêntrico, incapaz de considerar devidamente os outros seres e sistemas vivos integrados no cosmos.

Para o autor, esse igualitarismo entre espécies teria profundas implicações morais, pois

O movimento da ecologia profunda [implica]: (a) A rejeição da imagem do homem-no-ambiente em prol da imagem relacional a todo campo [e] (b) O igualitarismo biosférico - em princípio. A cláusula "em princípio" está inserida porque qualquer práxis realística implica necessariamente alguma matança, exploração e supressão. [Mas para] o trabalhador em campo ecológico o igual direito a viver e a se realizar plenamente é um axioma valorativo intuitivamente evidente e óbvio. Sua restrição aos seres humanos é uma forma de antropocentrismo que tem efeitos prejudiciais para a qualidade de vida dos próprios seres humanos. Essa qualidade depende em parte do prazer profundo e satisfação que recebemos da nossa parceria com outras formas de vida. A tentativa de ignorar nossa dependência e de instituir uma relação do tipo patrãoescravo tem contribuído para a alienação do homem de si mesmo. (Naess, 1989: 28)

Feitas essas considerações histórico-conceituais (ou genealógicas) sobre a percepção de alguns filósofos da identidade da revolução biotecnocientífica e com Jonas e Naess - sobre as consequências para uma suposta nova identidade da ética, mais ampla e integrada, podemos apresentar os principais argumentos em jogo quando se enfoca a moralidade dos atos biotecnocientíficos. 


\section{A Moralidade da Revolução Biotecnocientífica}

Como já lembramos, historicamente toda revolução, tanto social como cognitiva, sempre constituiu uma ruptura com os padrões culturais e comportamentais vigentes na época em que surgiu, razão pela qual não há, em princípio, nenhum motivo para que isso não devesse acontecer também com a revolução biotecnocientífica em curso. Mas, diferentemente do caso das revoluções científicas anteriores, com a vigência do paradigma biotecnocientífico temos algo inédito, pois parece ser a primeira vez na história humana que o homem tem não só o poder de transformar o mundo respeitando suas estruturas, mas também o de criar novas estruturas vivas e, sobretudo, de se modificar e autocriar, inclusive no sentido de se tornar uma nova espécie, supostamente mais adaptada ao seu meio em transformação - logo, de transformar potencialmente a própria estrutura do humano, inclusive a forma do juízo moral.

Porém, aqui surgem imediatamente também novas perguntas. Por exemplo: nessa nova condição antropológica, será que o Homo sapiens - que é também Homo faber e Homo creator - está evolutivamente preparado para essa nova capacitação e o novo tipo de responsabilidade decorrente? Ou - perguntando de outra maneira - será que ele sabe com suficiente certeza o que está fazendo e o que isso implica em termos de consequências não só imediatas, mas também futuras? Afinal, não é dito que ao novo poder de atuar, adquirido pela competência biotecnocientífica, corresponda uma nova competência moral que seja adequada aos desafios morais apresentados pela primeira. Ao contrário, pode muito bem ser que à potência e ao poder do saber-fazer biotecnocientífico corresponda uma incompetência do ponto de vista ético; ou seja, que o Homo faber sapiens e creator, competente do ponto de vista biotecnocientífico, seja de fato um Homo faber sapiens e creator que é também - como já vimos demens do ponto de vista moral.

Trata-se de questões evidentemente complexas e problemáticas, que mereceriam uma abordagem atenta a suas características e inter-relações. De fato, a biotecnologização do mundo vital tornou-se objeto de estudo, de questionamentos e de tomadas de posição bastante radicais, que configuram um campo discursivo bastante reduzido e polarizado entre dois tipos de destinatários: os que estariam sendo supostamente beneficiados e os prejudicados - 
apontando, assim, para uma ambivalência estrutural em sua percepção (que já indicamos pela imagem do Jano de duas faces). Em outras palavras, o processo sociocultural que leva o Homo faber sapiens da situação de desamparo à competência e às performances de Homo faber-sapiens-creator traz, para nós, contemporâneos, a suspeita de que essa nova competência humana se daria no contexto de uma equiprobabilidade de o ser humano ser Homo sapiens sapiens e Homo sapiens demens.

Entretanto, esse tipo de percepção (embora não referida explicitamente à suposta condição humana do Homo creator) é tão antigo quanto o antigo pensamento mitopoiético (recuperado pela literatura e, sobretudo, pelo cinema), que é o pensamento pré-racional que antecede o surgimento do pensamento sistemático e ordenado pelo logos, chamado filosofia, a qual, por sua vez é bom lembrar -, nasce também do espanto em relação ao desconhecido e ao impensado, mas, ao mesmo tempo, tenta detectar seu significado pela ordenação, descrição e compreensão dos construtos simbólicos e imaginários do humano.

Mas quais são, nesse novo contexto, os argumentos pró e contra os atos biotecnocientíficos e, em particular, contra os feitos da engenharia genética, em razão de seus possíveis efeitos sobre o real como um todo e sobre a vida humana em geral?

\section{A moralidade da intervenção programada sobre o genoma humano}

Como vimos, a expressão moralidade da engenharia genética é entendida aqui - de acordo com o significado técnico do termo moralidade, dado no começo deste ensaio - como análise crítica e normativa não somente dos efeitos positivos e moralmente aceitáveis da intervenção programada sobre o genoma humano, mas também dos negativos. Ou seja, o termo moralidade se refere ao conjunto de argumentos morais pró e contra a utilização da engenharia genética, argumentos baseados em escalas de valores e teorias morais não necessariamente (ou a priori) compatíveis entre si, sem, com isso, excluir a possibilidade de acordos e compromissos a posteriori.

Entrando mais nos detalhes, pode-se dizer que, via de regra, não existem argumentos morais substantivos contra a engenharia genética aplicada a 
plantas e animais não humanos, a não ser o argumento antigo (de origem aristotélica) - considerado por muitos como autoevidente-de que a engenharia genética estaria sempre e intrinsecamente errada porque interferiria no suposto finalismo intrínseco aos sistemas vivos (o que não passa de uma petitio principii questionável). Ou, então, o argumento utilitarista-consequencialista da necessária prudência e do obrigatório respeito aos padrões de biossegurança, que visariam, ambos, a garantir as melhores consequências mediante a ponderação de riscos e benefícios (o que analisamos detalhadamente no terceiro ensaio desta coletânea comparando as ferramentas da bioética com aquelas da biossegurança).

Objeções morais aparentemente mais substantivas surgem no caso da engenharia genética aplicada aos organismos humanos, sobretudo para fins melhorativos, facilmente associada a políticas eugenistas consideradas injustas porque discriminatórias, o que implica a necessária prudência diante de tais possibilidades biotécnicas transformadas em dispositivos biopolíticos e de biopoder. Porém, mesmo quando a objeção é fundamentada na prudência, o discurso não é muito claro, pois os argumentos racionais são dificilmente distinguíveis das emoções, razão pela qual é indispensável analisar os argumentos racionais separadamente, distinguindo os prós e os contras e explicitando sua eventual cogência, antes de tentar relacioná-los com suas expressões emocionais.

\section{Os argumentos favoráveis e contrários}

Em síntese, os argumentos a favor da aplicação da engenharia genética destacam suas potencialidades benéficas para prevenir e curar doenças e moléstias, ou para melhorar aptidões humanas consideradas desejáveis ou boas, e que constituiriam uma espécie de aprimoramento das capacidades humanas. Por sua vez, os argumentos contrários sublinham as potencialidades maléficas, visto que a engenharia genética poderia ser utilizada, por exemplo, para criar uma linhagem de super-humanos, supostamente capazes de escravizar o resto da população demasiado humana, ou para programar políticas discriminatórias aplicadas aos portadores de doenças e moléstias, ou simplesmente aos diferentes, como mostrariam as políticas e biopolíticas de tipo eugenista já adotadas no passado. Mas, nesse caso, haveria tanto um desrespeito 
injustificado à dignidade humana e à autodeterminação pessoal quanto alguma forma de injustiça social, visto que a programação genética poderia instaurar uma relação assimétrica e paternalista, na qual

o programador do programa dispõe, de maneira unilateral, sem ter pressuposto, de maneira justificada, o menor consentimento, sobre o material genético de outra pessoa com a intenção paternalista de colocar nos trilhos corretos a biografia desta outra pessoa, que dependerá desta intenção. (Habermas, 2001: 111)

Outra controvérsia diz respeito aos direitos das gerações futuras. Nesse caso, quem é contrário à engenharia genética argumenta que esta infringiria o direito fundamental - dos humanos por vir - a um genoma não manipulado, ao passo que para seus defensores a engenharia genética poderia ser o único meio de assegurar a sobrevivência da espécie em condições adversas no futuro. Mas, aqui, existe o problema de saber como atribuir direitos sem a contrapartida dos deveres, razão pela qual se pode argumentar que o termo direitos, aplicado a sujeitos potenciais, tem, na melhor das hipóteses, um sentido meramente analógico, embora Hans Jonas (2006) já argumentasse no sentido de deveres para com sujeitos de direitos ainda não existentes.

\section{Os referenciais deontológicos, teleológicos e utilitaristas}

Os argumentos pró e contra o uso das ferramentas biotecnocientíficas pertencem, substancialmente, a três tipos de teorias morais:

1) As deontológicas, que se referem às obrigações relativas aos deveres do agente moral e, em particular, aos deveres dos profissionais, inclusive em nosso caso - dos profissionais da engenharia genética, e aos limites decorrentes a serem eventualmente impostos à prática da manipulação genética. Entretanto, as deontologias não respondem satisfatoriamente à pergunta "por que devemos agir moralmente de determinada maneira em determinada situação específica?", a qual pode afetar diretamente a análise e entrar em conflito com algum outro dever (como no caso dos dilemas morais conhecidos como escolhas de Sofia).

2) As teleológicas, que se referem aos supostos fins ou desígnios (ou causas finais) dos organismos e sistemas naturais, e que os consideram pertinentes para avaliar as ações, que serão julgadas positivas ou negativas 
de acordo com suas consequências, ponderando, por exemplo, se a manipulação genética respeita ou não o finalismo intrínseco, ou telos, dos processos naturais. Entretanto, também as teleologias têm seus limites, pois não conseguem explicar suficientemente por que os processos e as coisas teriam causas finais.

3) As utilitaristas, que podem ser vistas como um desdobramento (ou subconjunto) das teleológicas, as quais se referem substancialmente à utilidade social e consistem em ponderar a melhor relação possível entre probabilidades dos riscos e das esperanças dos benefícios, mas podem não ter em devida conta, por exemplo, os interesses das minorias (necessariamente subsumidos àqueles da maioria).

$\mathrm{Na}$ prática, os três tipos de argumento podem se tornar complementares quando se queira sair de um impasse e chegar a um acordo, isto é, quando a ética pretende encontrar convergências no ethos atravessado pela conflituosidade, para utilizar os termos de Ricardo Maliandi (2006). Por exemplo, quando os mesmos argumentos utilitaristas podem servir tanto para justificar quanto para condenar alguma intervenção no genoma, será preciso recorrer a argumentos adicionais, de tipo teleológico ou deontológico. De fato, como indicamos, o utilitarismo e o consequencialismo são muito próximos, pois o útil pode ser visto também como consequência de um ato, e a deontologia deverá, de algum modo, dialogar com o consequencialismo e o utilitarismo para não se restringir ao âmbito das boas intenções necessárias para respeitar deveres.

\section{Os argumentos a favor da intervenção sobre o genoma humano}

Os principais argumentos a favor da legitimidade moral da intervenção são os seguintes:

1) $O$ argumento terapêutico, com que se pretende legitimar a intervenção para a cura de doenças e moléstias, isto é, para eliminar um dano atual. Em particular, esse argumento legitima a intervenção sobre as células somáticas dos indivíduos existentes, na qual se tenta remover causas de sofrimentos considerados em princípio evitáveis. Trata-se de um argumento que podemos chamar de utilitarista negativo, e contra ele não 
parece haver contra-argumentos muito cogentes, visto que o argumento terapêutico é considerado perfeitamente razoável, pelo menos de um ponto de vista sanitário e pressupondo uma sociedade secular e laica na qual o martírio e a santidade constituem mais a exceção do que uma regra imposta a todos. Ademais, se não aceitássemos esse argumento, a rigor nenhuma intervenção médica seria legítima. No entanto, o argumento terapêutico deve enfrentar a questão de seus excessos, como a obstinação terapêutica contra qualquer tipo de doença e moléstia, o que pode resultar em uma espécie de medicalização de toda a sociedade ou em biopolíticas questionáveis, acrescentando, no mesmo movimento, mais sofrimento ao mundo.

2) $O$ argumento preventivista, com que se visa a legitimar a intervenção para prevenir doenças e moléstias. Podemos chamar também esse argumento de tipo utilitarista negativo, uma vez que a ele se recorre com a intenção de evitar danos futuros ou potenciais, o que é também em princípio razoável e moralmente defensável. Entretanto, nesse caso uma prevenção efetiva implicaria intervir também sobre a linha germinal para que as modificações introduzidas pela engenharia genética fossem transmitidas aos descendentes, isto é, agindo em prol de um possível maior bem-estar futuro, visto que poderiam propiciar uma descendência mais saudável ou, pelo menos, menos doente. E isso pode criar um verdadeiro dilema moral, pois se é razoável, por um lado, defender a intervenção sobre a linha germinal, considerando que serviria para eliminar danos e sofrimentos em princípio evitáveis, por outro, uma vez que as transformações - herdadas pelos descendentes - serão em princípio irreversíveis, podem surgir fortes dúvidas (e objeções) sobre riscos potenciais e a longo prazo, devido às próprias transformações genéticas introduzidas, que poderiam se revelar, afinal, iatrogênicas e sem volta. Há também os riscos biopolíticos e antidemocráticos de uma biocracia autoritária, como aquela que pretendesse impor estilos de vida ditos saudáveis a todos, e a eugenia, que pretende controlar ou melhorar a qualidade da descendência, mas pode implicar políticas discriminatórias como aquelas praticadas durante o nazismo. De qualquer maneira, é perfeitamente razoável defender a ideia de que não 
há nenhuma diferença relevante, no plano moral, entre intervenção sobre a linha somática e a linha germinal, desde que controlados os eventuais riscos, operação que - como vimos - é algo também incerto e questionável.

3) $\mathrm{O}$ argumento da beneficência e da não maleficência, com o qual se visa a legitimar a intervenção, porque quando é possível fazer um bem (ou evitar um mal) seria razoável afirmar que devemos fazê-lo, ao invés de não fazê-lo. Esse argumento, essencialmente de tipo deontológico, corresponde à ética médica tradicional, embasada nos princípios hipocráticos da não maleficência e da beneficência, e pode ser formulado também de outra forma: "somos moralmente responsáveis tanto pelo mal que fazemos quanto pelo mal que poderíamos ter evitado", visto que não há uma diferença moral substantiva entre causar dano e sofrimento, por um lado, e deixar que isso aconteça, por outro. Nesse caso, a única objeção relevante seria aquela segundo a qual só podemos ser benevolentes com alguém se o possível destinatário de nosso ato cognitiva e moralmente competente - aceitar que o sejamos, isto é, se respeitarmos sua autonomia para decidir o que é melhor para ele, e independentemente de ele estar "certo" ou "errado" (conforme nossos parâmetros). Em outros termos, tal tipo de argumento entra, muitas vezes, em conflito com o princípio do respeito da autonomia pessoal, o que não pode ser menosprezado, pois foi graças a esse princípio que se tornou possível criticar, nas últimas décadas, o paternalismo médico.

4) $\mathrm{O}$ argumento da autonomia pessoal, segundo o qual a livre vontade individual é condição necessária e suficiente para utilizar qualquer tipo de terapia gênica (tanto a somática quanto a germinal), desde que isso não crie um dano real para terceiros. Entretanto, nesse caso, podem surgir conflitos entre o princípio do respeito à autonomia pessoal e o princípio da justiça, relativo, por exemplo, à alocação equitativa dos recursos disponíveis em determinada situação sanitária. Com efeito, e sem entrar aqui nos detalhes dessa discussão, é prima facie razoável afirmar a legitimidade moral de intervir na vida de alguém se isso corresponder a seus melhores interesses (embora muitas vezes em contraste com seus desejos) e se a intervenção for aceita por um destinatário (pelo menos 
razoável), pois tais interesses podem não ser satisfeitos; por exemplo, quando houver outros interesses mais fortes (como a proteção da saúde do maior número).

\section{Os argumentos contrários à intervenção sobre o genoma humano}

Os principais argumentos contrários à intervenção sobre o genoma humano são:

1) O argumento da ladeira escorregadia (slippery slope argument), segundo o qual deveríamos evitar fazer algo - mesmo que isso resultasse em um bem atual - para evitar eventuais danos ou abusos futuros. Aplicado à intervenção sobre o genoma humano, esse argumento implica que o risco de abusos seria razão suficiente para não fazê-la. Em regra, tal argumento é utilizado para prevenir o risco de políticas eugênicas de tipo discriminatório (como as já lembradas políticas eugenistas da biocracia nazista). Embora pertinente em casos-limite - nos quais esse tipo de risco é efetivamente preponderante -, o argumento é em regra pouco consistente, porque preconceituoso e porque pressupõe - como alternativa e de forma irrealista e simplista - uma sociedade de risco zero, quando sabemos que as sociedades complexas são de fato sociedades do risco estrutural. Ademais, se o aceitássemos sem mais, não teríamos, por exemplo, a maioria das substâncias e dos procedimentos que permitiram melhorar, de forma significativa, nosso bem-estar humano, e correríamos o risco real de não nos prevenirmos contra riscos futuros.

2) O argumento teleológico, segundo o qual a utilização da engenharia genética seria uma forma não natural e arrogante de interferir no finalismo intrínseco dos processos naturais, garantido por uma suposta sabedoria evolutiva (não necessariamente de origem divina). Esse argumento é uma versão forte do anterior e, muitas vezes, vem acompanhado de um argumento adicional - de tipo teológico segundo o qual a utilização da engenharia seria fazer o papel de Deus, o que interferiria, de forma indevida, nos planos de uma pressuposta sabedoria divina norteadora. A principal fragilidade do argumento do respeito ao finalismo intrínseco está na desconsideração de que o humano é, na melhor das hipóteses, um ser natural sui generis, e isso 
desde que começou o processo de hominização: como ser na origem neoténico, ele precisa da cultura, inclusive da cultura tecnocientífica e biotecnocientífica, para satisfazer seus interesses e desejos, e pode, inclusive, precisar da engenharia genética para garantir a qualidade da sua vida e a daquela das gerações futuras.

3) O argumento do direito a um genoma não modificado, como condição para a preservação dos direitos humanos fundamentais, a começar pelo direito à autonomia pessoal, que seria em princípio seriamente prejudicado pela modificação do genoma humano. Esse argumento é problemático porque pressupõe que a preservação da integridade do genoma seja condição necessária para a preservação da autonomia pessoal. Implica, portanto, que nós somos essencialmente nosso genoma, pois tudo o que nos diz respeito estaria, em última instância, determinado por nossos genes, o que é - pelo menos de acordo com o estágio atual do conhecimento - uma confusão patente entre identidade orgânica e identidade pessoal (que os avanços no campo das neurociências talvez possam ajudar a resolver).

4) Oargumento da equidade, segundo o qual, perante os problemas urgentes e prioritários da saúde pública, a intervenção no genoma constituiria um desvio ilegítimo de parte significativa dos parcos recursos disponíveis para privilegiar uma minoria. Esse argumento é complementar ao anterior e aparentemente procede, pois levanta, de forma pertinente, a bandeira da justiça distributiva dos bens existentes, inclusive aqueles propiciados pela vigência do paradigma biotecnocientífico. Entretanto, não considera a possibilidade de tal intervenção se tornar uma necessidade para o bem-estar do maior número de pessoas, e até para a sobrevivência da própria espécie humana em condições ambientais adversas, caso em que a intervenção no genoma seria prima facie justificada.

\section{Considerações críticas sobre os dois tipos de argumento}

Tais são, evidentemente, apenas alguns argumentos pró e contra a intervenção biotecnocientífica sobre o genoma humano. Porém, o que se pode dizer ao analisar as argumentações aqui apresentadas é que, em regra, é mais fácil 
encontrar as falhas dos argumentos contrários ao uso desses novos produtos e procedimentos do que propor uma teoria consistente e propositiva em favor da engenharia genética, quando ela implique a transformação da chamada natureza humana. As razões são, provavelmente, muitas. Além da já citada relativa novidade do paradigma biotecnocientífico, o qual inevitavelmente leva a uma série de medos, justificados ou não, é possível que a moralidade do mundo contemporâneo esteja em um momento de transição paradigmática que indicaria uma transformação antropológica em curso, a qual implicaria também a possível emergência de uma nova moral, embora - seguindo certo consenso atual entre especialistas em ética e bioética - o mais provável seja uma consolidação do pluralismo moral atual, faute de mieux.

Ou seja, o que, provavelmente, está em jogo, por trás das críticas à engenharia genética, é o contraste entre dois tipos de moral: a moral tradicional, norteada essencialmente pelos argumentos da naturalidade e da identidade entre os desígnios divinos e a teleologia dos processos naturais, e baseada substancialmente em deveres absolutos e na interdição de transgredir uma suposta ordem constituída, segundo a qual haveria conhecimentos em princípio proibidos; e outra moral em formação, cujos princípios são reconhecidamente históricos e contextuais, e cujos deveres só podem ser considerados válidos prima facie, segundo as contingências históricas e a configuração do imaginário social de acordo com tais contingências.

De fato, a moral tradicional está baseada numa dupla interdição: a) aquela segundo a qual a vida humana é da ordem do sagrado, não podendo, portanto, ser violada (não entraremos aqui no mérito da polissemia do termo sagrado, que abordamos no terceiro ensaio com base nas reflexões de Agamben), a não ser por algum desígnio divino, que pontualmente os representantes de deus na Terra poderiam eventualmente interpretar; b) aquela segundo a qual os supostos desígnios divinos coincidiriam com a ordem natural e, portanto, transgredir as leis naturais implicaria transgredir a ordem divina e vice-versa.

Já a moral contemporânea (cujas raízes se situam no humanismo da Renascença e do Iluminismo) é em princípio racional e secular, e sua legitimidade não se situa (prevalentemente) nem na lei divina nem nas leis naturais, mas, substancialmente, na racionalidade dos argumentos que a defendem e na eventual negociação entre sujeitos e comunidades morais, mesmo que 
isso implique - em determinadas circunstâncias - a transgressão das leis ditas naturais.

Ademais, não podemos esquecer que a transgressão das leis naturais é um fenômeno típico da cultura humana, produto - como já vimos - do processo de hominização. Ela se dá desde pelo menos a transgressão das leis da gravidade pela aviação até a transgressão da medicina - pelo menos desde que esta soube reverter os decursos normais das doenças pela administração de antibióticos, pelas cirurgias e, atualmente, pela genômica. Em outros termos, a cultura é sempre, de alguma forma, uma antinatureza ou um processo transgressivo. Com efeito, foi uma série de transgressões que permitiu melhorar sensivelmente a qualidade de vida de muita gente, como no caso daqueles indivíduos não privilegiados pela "mãe natureza", porque mais sujeitos (ou suscetíveis) a doenças e moléstias. Por que, então, deveríamos confiar mais nas leis naturais e nos acasos de doença e saúde, e menos na competência humana para transpor os limites naturais de nossa condição humana? Em realidade, o ser humano introduz no seu mundo vivido um ethos formado por valores como a justiça sanitária, o respeito à autonomia individual, os princípios da não maleficência, da beneficência, da responsabilidade individual e coletiva, dentre outros, e os considera como patrimônio comum possível da humanidade. Como de fato aconteceu com a criação, após a Segunda Guerra Mundial, da Declaração Universal dos Direitos Humanos (1948). Por que, então, não considerar válidos tais princípios e valores, independentemente do fato de sua aplicação respeitar ou não os supostos desígnios divinos - sobre cuja interpretação já houve guerras de religiões, fogueiras e tantos outros abusos contra aqueles valores hoje chamados de direitos humanos fundamentais - ou as leis naturais - que, como nos ensina a história da ciência, são, muitas vezes, novamente interpretadas? Essas são algumas questões que merecem reflexão, antes de se levantar os escudos contra as supostas transgressões malignas perpetradas pela engenharia genética.

Evidentemente, os deslizes são sempre possíveis, sobretudo os de cunho autoritário, como salientam as declarações internacionais, uma vez que a engenharia genética pode se tornar um meio para políticas eugênicas ou imunitárias discriminatórias voltadas para indivíduos e populações considerados mal adaptados ou até inferiores, além de ferir o princípio de 
respeito à autonomia das gerações futuras (destacado por Habermas), visto que estaríamos decidindo em seu lugar o que deveria ser melhor para elas e, sobretudo, sem seu consentimento - evidentemente impossível de ser obtido. Mas esse tipo de crítica tem a ver com a terapia genética da linha germinal porque esta pode manipular o genoma dos futuros seres, dispondo, assim, sobre o que provavelmente será sua identidade e suas reais possibilidades de escolha.

Entretanto, esse tipo de crítica merece dois comentários. Em primeiro lugar, deve-se considerar que nós não somos (apenas) os nossos genes (como tampouco somos apenas nosso corpo biológico), mas somos, também (ou sobretudo), o produto de nossa história pessoal, familiar e social, de nossa cultura, de nossas experiências feitas com nossos corpos e nossos espíritos. Em outros termos, somos nossas biografias. Em segundo lugar, sofremos também os efeitos (positivos e negativos) de nossa educação, dos hábitos e dos valores morais apreendidos em nossas culturas e épocas respectivas, o que não nos impediu de avaliar criticamente tal herança cultural e de, muitas vezes, optar por outros valores e hábitos, diferentes e considerados, por alguma boa razão, melhores. Se isso faz sentido, por que então a transformação e determinação do patrimônio genético seria uma forma pior de violar nossa autonomia pessoal do que a educação ou qualquer outra forma de intervenção médica ou sanitária? Ademais, se é verdade que em ciência nunca se deveria dizer aprioristicamente nunca - pois corremos o risco de sermos refutados posteriormente pelos fatos - e supondo que as gerações futuras decidam baseadas nos dados atualizados do Projeto Genoma Humano - que é melhor recuperar alguma característica do passado, revertendo, portanto, as transformações adquiridas, quem e o que as impediria? Uma impossibilidade real? A incompetência humana? O acaso?

As questões aqui delineadas são, evidentemente, complexas e delicadas, e a maioria dos argumentos morais pró e contra pertence à grande zona cinzenta do saber e da moralidade (ou ethos) encarada pela ética aplicada e pela bioética, pois os fatos aos quais se referem se inscrevem em um ambiente de incertezas, tanto cognitivas como operacionais. Por isso, essa zona cinzenta é um lugar de conflitos e dilemas morais atuantes, que demandam análises muitas vezes longas e difíceis, e cujas soluções podem ser, na maioria das 
vezes, contraintuitivas, obrigando-nos a rever constantemente, e com espírito crítico, nossos paradigmas e sistemas de valores. Aliás, se os problemas não fossem complexos, provavelmente não precisaríamos de uma nova disciplina como a bioética, pois a ética tradicional e o respeito à sabedoria do passado provavelmente seriam suficientes.

Entretanto, mesmo complexos (ou provavelmente por isso mesmo), os problemas devem ser enfrentados, para evitar fundamentalismos (tanto religiosos como laicistas) que, quase sempre, prejudicam o bem-estar da maioria da população, pois implicam, muitas vezes, princípios que mal se integram à moralidade efetiva das sociedades democráticas e pluralistas.

Mas, para garantir (ou tentar garantir) uma abordagem que possa ser considerada pelo menos razoável da conflituosidade implicada pela genômica, precisamos de uma análise paciente dos argumentos em jogo, que seja a mais racional e imparcial possível, e, também, respeitosa para com as crenças pessoais e as comunidades morais específicas afetadas, desde que estas não prejudiquem concretamente o interesse coletivo (como no caso de fanatismos e fundamentalismos). Portanto, parece razoável e moralmente justificável afirmar que devemos tolerar alguma forma de constrangimento, pois somente assim podemos conviver num mundo em que os interesses e valores legítimos são muitos e, quase sempre, em conflito entre si, nos obrigando a construir os indispensáveis pontos de convergência, necessários para uma convivência pelo menos tolerante e civilizada.

A principal consequência disso tudo é que, provavelmente, não é mais possível, atualmente, uma moral geral comum, isto é, uma moral forte ou abrangente, capaz de gerar consenso de todos sobre os sistemas de valores a serem adotados. O que é possível é apenas uma moral (que pode eventualmente ser vista como uma colcha de retalhos) resultante de desacordos entre pessoas razoáveis que procurem alguma forma de convergência entre atores sociais distintos, com interesses em conflito, mas capazes de convergir sobre alguns bens primários que devem ser equitativamente compartilhados.

No caso específico da engenharia genética não existe consenso, nem uma teoria moral que a justifique em qualquer circunstância. Entretanto, podese dizer também que os argumentos contrários resultam, na maioria das 
vezes, mais de medos injustificados (ou pelo menos exagerados) e de reações prevalentemente emocionais do que de perigos reais, sobretudo se encararmos a intervenção sobre o genoma humano do ponto de vista sanitário e de acordo com a postura de uma ética laica e pluralista.

A bioética em genômica parece, portanto, sugerir não tanto a atitude de ser a priori contra ou a favor da intervenção sobre o genoma humano (ou de outras espécies), mas sim um acompanhamento de tais intervenções pela sociedade civil informada e capacitada (ou empoderada), a começar pelo acompanhamento das pesquisas em genômica. Como já acontece, inclusive no Brasil, com a pesquisa envolvendo seres humanos, avaliada pelos comitês de ética em pesquisa, como no sistema brasileiro Comitês de Ética em Pesquisa/ Comissão Nacional de Ética em Pesquisa (CEP/Conep).

Trata-se de tarefa certamente difícil quando se consideram não só os grandes princípios éticos, mas também e, sobretudo, os riscos de o paradigma biotecnocientífico não ser acompanhado de perto pelo paradigma bioético. O papel deste paradigma não é apenas dar a entender a conflituosidade constitutiva de toda práxis humana; cabe-lhe também uma tarefa normativa, a qual visa em particular a proscrever comportamentos considerados fontes de danos e sofrimentos evitáveis e tentar, dessa maneira, construir convergências capazes de resolver os conflitos de interesses e valores que perpassam as práticas humanas que envolvem outros humanos e outros seres vivos não humanos, situados em seus ambientes.

\section{Os conflitos teóricos na própria ética}

Essa tarefa prática não é, entretanto, consensual dentro do próprio campo da ética. Este, como vimos, encontra-se dividido entre quem considera a ética como sinônimo de moral e quem separa a ética da moral, considerando a primeira a ciência da moral, a qual tem por objeto de estudo não tanto os comportamentos humanos (estudados por outras ciências humanas e sociais específicas, como psicologia, antropologia e sociologia), mas os juízos de valor, negativos e positivos, sobre tais comportamentos, por considerar que "os juízos de valor sobre a conduta são fatos reais" (Lalande, 1972a: 306). Ademais, para aqueles que separam claramente a ética da moral, a primeira deveria se ocupar também do problema da justificação dos enunciados morais pertencentes à 
moral. Algo parecido acontece entre aqueles que consideram a ética como discurso de segunda ordem sobre os discursos de primeira ordem referentes aos sistemas de valores e crenças acerca do bem/bom e do mal, do correto e incorreto, do justo e injusto, vigentes no espaço e no tempo, representados pela moral. De acordo com essa concepção da ética - conhecida também como metaética (e que abordamos especificamente no primeiro ensaio desta coletânea) -, a ética deveria analisar, da maneira mais racional e imparcial possível, apenas os conflitos morais - como se pretende metodologicamente de qualquer forma de saber suficientemente organizada e consistente que pretenda ter direito ao qualificativo "discurso de segunda ordem".

Essa segunda vertente não é desprezível historicamente. A distinção entre sistemas morais vigentes e outros sistemas representados pelas análises críticas dos primeiros, isto é, a separação entre discursos de primeira ordem (como a moral) e discursos de segunda ordem (como a ética), permitiu vislumbrar (embora com muitas dificuldades teóricas e práticas, como também vimos no primeiro ensaio desta coletânea) a possibilidade de que um ponto de vista universal ou objetivo relativo aos sistemas de primeira ordem referidos aos valores morais vigentes venha a dirimir conflitos não dirimidos por outros meios (por exemplo, pelo direito).

Formalmente, a necessidade de ocupar o lugar de um discurso de segunda ordem em ética foi fortemente defendida - e com bastante sucesso pelo menos em âmbito anglo-saxônico - durante quase um século pela ética analítica. Esta, iniciada com a obra de Henry Sidwick The Methods of Ethics, de 1874, só encontra críticos de peso quando, entre o fim da Segunda Guerra Mundial e o surgimento dos vários movimentos de contestação e reforma da ordem vigente nos anos 60 do século XX, se dão as condições para que surjam também as éticas aplicadas. Depois que se soube abertamente das práticas humanas contra outros humanos verificadas na Armênia, em Auschwitz, Hiroshima, Nagasaki e tantos outros abusos e extermínios cometidos em situações de guerra (mas também em situações de paz aparente), a ética precisou de um upgrade radical para poder se renovar e não ser simplesmente reduzida às análises de segunda ordem.

É nesse processo de complexificação das relações entre vida teórica e vida prática, mas também entre discursos e metadiscursos (ou discursos de segunda 
ordem), que surge, já nos anos 70 do século XX, aquela que poderíamos chamar de ética analítica dos casos concretos, que nada mais seria que uma aplicação das ferramentas conceituais e metodológicas (desenvolvidas com rigor e sucesso durante os quase cem anos de duro labor analítico) aos novos conflitos e dilemas morais surgidos da acrescida competência (e potência e poder) do humano para direcionar seu destino.

Entretanto, aqui também fica uma questão em aberto: a de saber o que possam legitimamente fazer as ferramentas da ética e da bioética para controlar as pesquisas e evitar sua eventual iatrogenia, pois - de acordo com uma boutade bastante lembrada e atribuída a Albert Einstein - fazer pesquisa é algo demasiado importante para que as decisões sejam deixadas nas mãos apenas dos próprios cientistas, que podem, por exemplo, estar envolvidos em conflitos de interesses ou em fraudes, como qualquer cidadão comum. Nesse sentido, vale a pena lembrar o caso da conflituosidade inerente às práticas da indústria farmacêutica, denunciada, por exemplo, pela antiga editora-chefe do New England Journal of Medicine, Marcia Angell, para quem tal indústria "afastou-se enormemente do seu nobre propósito original de descobrir e produzir novos medicamentos úteis" para tornar-se "uma máquina de marketing para vender medicamentos de benefício duvidoso [que] usa sua fortuna e seu poder para cooptar cada instituição que possa se interpor em seu caminho" (Angell, 2007: 16).

Em razão dos enormes interesses em jogo, seria atualmente demasiado arriscado que os profissionais continuassem conspirando - consciente ou inconscientemente - contra os leigos (como já afirmara no século XVIII o escritor inglês Jonathan Swift), e a prova do caráter altamente problemático da pesquisa que envolve seres humanos seriam os inúmeros abusos cometidos, ao longo do século XX, por especialistas do campo que hoje chamamos de ciências da vida e da saúde contra os direitos humanos, em regimes tanto ditatoriais como democráticos, amplamente relatados desde os anos 1960, inclusive pela emergente bioética. 


\section{O que Fazer, Então?}

Quais são, em definitivo, os principais problemas éticos levantados pela genômica na vigência do paradigma biotecnocientífico em um mundo cada vez mais globalizado?

Dentre os principais objetos de questionamentos éticos já feitos recentemente (eugenismo, monopólio da informação genética, patenteamento da vida, discriminação de portadores de características suscetíveis de adoecimento), os mais problemáticos, em uma sociedade democrática e pluralista, são provavelmente aqueles que dizem respeito às tentativas de monopólio, via patenteamento, das informações que de direito pertencem a cada um e a todos. Afinal, o genoma humano, contrariamente aos alfabetos, não é uma invenção stricto sensu, mas a descoberta de algo real, mesmo que simbolizado e codificado de acordo com uma linguagem determinada. O risco, nesse caso, é em primeiro lugar que o genoma humano se torne mera mercadoria - na feliz expressão dos bioeticistas Giovanni Berlinguer e Volnei Garrafa (1996) -, aumentando a probabilidade de aprofundamento da conflituosidade social e da injustiça. A redução desse grande invento que é o Projeto Genoma Humano à mera dimensão mercadológica e excludente parece contradizer a própria tradição da ética científica, que, apesar de algumas manchas muito graves (como a "colaboração" de alguns cientistas em regimes totalitários), se enraíza, em princípio, no amor pelo conhecimento e na preocupação com a melhoria da condição humana.

Em uma sociedade democrática em que a cidadania seja efetivamente exercida e haja, portanto, algum empoderamento da sociedade civil e de todos os seus cidadãos, é importante considerar a percepção social sobre os fatos tecnocientíficos e biotecnocientíficos. Mas, como vimos, o campo das percepções sociais das práticas da biotecnociência está dividido, grosso modo, entre dois extremos: por um lado, os tecnofílicos, para os quais qualquer nova tecnologia e biotecnologia serão bem-vindas, sem que se preocupem com seus eventuais efeitos adversos presentes ou futuros; por outro, os tecnofóbicos, para quem a biotecnociência estaria desenvolvendo poderes capazes de transformar o mundo e o próprio homem indevidamente, prejudicando, inclusive, os melhores interesses das gerações futuras (que são de fato inferidos, sem mais, a partir dos atuais). 
Entre os dois extremos, entretanto, há um meio-campo em construção e bastante complexo, no qual podemos identificar pelo menos três posições distintas.

1) A primeira é aquela dos adeptos do princípio de precaução, princípio moral próximo do antigo princípio de não maleficência, mas situado em condições de incerteza, e que defende a obrigação de se abster de uma ação quando esta pode ter consequências danosas para os envolvidos. De fato, o princípio de precaução é um princípio sui generis - em parte herdeiro da antiga prudência aristotélica, ou phronesis - e de pouca utilidade prática em situações problemáticas complexas, pois não se baseia em probabilidades de ocorrência de danos claramente identificáveis; não especifica a natureza de tais danos e, sobretudo - de acordo com um argumento consequencialista -, se o adotássemos nunca teríamos a certeza de que os fatos da biotecnociência terão consequências positivas ou não, se são úteis ou não, e em caso positivo, em que condições e para quem. Por isso, seus defensores devem responder às críticas que consideram o princípio precautório como, muitas vezes, um empecilho ao desenvolvimento e às mudanças consideradas necessárias para a própria sobrevivência da espécie humana em um mundo em rápida transformação. Segundo tais críticas, a aplicação de tal princípio pode implicar a inação, a qual tem também suas consequências e demanda assumir responsabilidades pela privação dos eventuais benefícios que a biotecnociência poderia trazer para a condição humana (Balistreri, 2002).

2) A segunda posição se baseia no princípio de responsabilidade, de acordo com a proposta inicial de Hans Jonas, referida à ética de responsabilidade de Max Weber, que a distinguia da ética da conviç̧ão, como relatado pelo próprio Jonas em uma conferência de 1986, feita contra um niilismo supostamente reinante nas sociedades modernas, democráticas e individualistas (Jonas, 1987). A ética da responsabilidade - decorrente desse princípio - preocupa-se corretamente não só com o presente, mas também com o futuro da espécie humana e com o impacto das ações humanas sobre os processos naturais e sociais, considerados cada vez mais ameaçados e ameaçadores, partindo do pressuposto de que 
os processos naturais seriam orientados por um finalismo intrínseco a ser em princípio respeitado. Por isso, a ética da responsabilidade implicaria uma política de homens prudentes, preocupados em proteger a existência humana a longo prazo e sabendo que a sobrevivência do ser humano dependeria da preservação dos processos naturais como são, e não da transformação da natureza e da natureza humana naquilo que queremos que sejam. Entretanto, e apesar do mérito de ter destacado a responsabilidade para com as gerações futuras, um dos problemas da ética jonasiana é sua concepção da evolução, que desconsidera a contingência e o acaso dos processos naturais, substituídos pelo finalismo intrínseco a ser absolutamente respeitado e que interditaria ao humano intervir em sua própria evolução.

3) A terceira posição considera que a biotecnociência pode ser em princípio benéfica para os humanos presentes e futuros, no sentido de constituir um meio a serviço dos ideais morais e políticos de justiça, igualdade e emancipação. Formulada por Karl-Otto Apel e Jürgen Habermas, é conhecida como ética procedimental da discussão, constituída por uma argumentação sem restrições entre todos os envolvidos em uma controvérsia moral, com todos compartilhando o objetivo de um consenso racional, adotado livremente por todos os envolvidos em uma disputa e que seja capaz de evitar tanto medidas autoritárias do estado de exceção - desrespeitoso dos direitos humanos (Apel, 1987) - quanto o "eugenismo liberal" (Habermas, 2001). Embora seja uma tentativa de evitar as dificuldades tanto da ética da precaução como da ética da responsabilidade, essa posição pode também ser criticada devido, essencialmente, a seu idealismo (compartilhado em parte também pela ética da responsabilidade): ela pressupõe que a única forma de emancipação humana seja de tipo simbólico (ou comunicativo), e não também técnica e prática - ou seja, por pressupor que "não existe evolução humana; só existe a história humana, que é fundamentalmente simbólico-espiritual, e não tecnomaterial" (Hottois, 2005: 112, destaques do original). A segunda característica criticável seria seu conservadorismo naturalista e, consequentemente, sua "concepção demasiadamente negativa da técnica", incapaz de ver 
"que as intervenções biológicas poderiam contribuir para tornar os seres humanos menos desiguais no nascimento e mais capazes de superar as alienações", graças, inclusive, ao "impulso das biotecnologias e da biomedicina", em vez de ver apenas "os aspectos destruidores e liberticidas do progresso tecnocientífico" e desprezar "totalmente a extraordinária criatividade deste progresso, que não cessa de enriquecer o real (...) [e] as imensas capacidades de conservação, preservação, de guardar na memória e mesmo de 'ressurreição' que as tecnociências não param de desenvolver" (Hottois, 2005: 122-126).

Resumindo, a ética procedimental da discussão seria criticável porque por um lado reconheceria o poder do simbólico, mas por outro desconheceria as potencialidades emancipatórias da biotecnociência e a possibilidade que esta teria de enriquecer a própria natureza humana, em vez de considerá-la como bode expiatório "de todas as disfunções, injustiças, carências de nossa civilização multicultural e tecnocientífica em vias caóticas de globalização". Tal desconhecimento teria consequências moralmente importantes, pois, como argumenta ainda Hottois, "[a] tecnocientofobia associada ao conservadorismo naturalista tornou-se um verdadeiro obstáculo epistemológico, impedindo que se identifiquem e incriminem as verdadeiras áreas responsáveis", que são as "hierarquias políticas, econômicas e financeiras", e se a biotecnociência pode ser mal utilizada, isso se deve, muito mais, "ao que se continua a chamar 'a natureza humana', à falta de consciência e de grandeza de coração e de espírito, à finitude e à malignidade dos seres humanos" (Hottois, 2005: 129-130).

É nesse contexto discursivo e argumentativo que se situa a moralidade da genômica, abordada pela bioética e cuja problemática tentamos aqui delinear. 